\title{
Sustainable Technologies for Small-Scale Biochar Production-A Review
}

\author{
Hussein Kisiki Nsamba1,2,3*, Sarah E. Hale4, Gerard Cornelissen, Robert Thomas Bachmann1 \\ ${ }^{1}$ Malaysian Institute of Chemical and Bioengineering Technology (MICET), Universiti Kuala Lumpur, \\ Kuala Lumpur, Malaysia \\ ${ }^{2}$ Section of Industrial Chemistry, Department of Chemistry, Makerere University, Kampala, Uganda \\ ${ }^{3}$ Invention Plus Limited, Kampala, Uganda \\ ${ }^{4}$ Norwegian Geotechnical Institute (NGI), Oslo, Norway \\ Email: hnsamba@cns.mak.ac.ug
}

Received 11 February 2015; accepted 1 March 2015; published 5 March 2015

Copyright (C) 2015 by authors and Scientific Research Publishing Inc.

This work is licensed under the Creative Commons Attribution International License (CC BY). http://creativecommons.org/licenses/by/4.0/

c) (i) Open Access

\section{Abstract}

Charcoal has found enormous application in both agriculture (AKA biochar) and other sectors. Despite its potential benefits, small scale technologies relevant for its production remain a challenge. Technologies striking a balance between user friendliness, energy efficiency, ease of adaptation and limited emissions could easily be integrated into the local community for the sustainable production of biochar answering both technical and socio-economic aspects. These technologies can be customized to recover the produced heat alongside biochar and the producer gas. The purpose of this work is to review the state of the art in small scale technologies, their associated risks and challenges as well as research gaps for future work. Factors affecting biochar production have been discussed and temperature is known to heavily influence the biomass to biochar conversion process. Based on the reviewed work, there is a need to develop and promote sustainable and efficient technologies that can be integrated into biochar production systems. There is also further need to develop portable, economically viable technologies that could be integrated into the biochar production process without compromising the quality of produced biochar. Such technologies at midscale level can be channeled into conventional small scale farmer use in order that the farmers can process their own biochar.

\section{Keywords}

Biochar, Technologies, Small Scale, Sustainable, Farmers

\footnotetext{
${ }^{*}$ Corresponding author.
} 


\section{Introduction}

Biochar is the carbon-rich product obtained when biomass is heated in a closed container with little or no available air through a process called pyrolysis [1]. Biochar is a pyrogenic black carbon that has attracted increased attention in both political and academic arenas [2]-[12]. The ability to attract such a global attention is due to biochar's potential to mitigate climate change [3] [13] provide food security [14] as well as providing an alternative for organic waste management [2]. Application of biochar to soils is currently gaining considerable interest globally due to its potential to improve soil nutrient retention capacity, water holding capacity and also to sustainably store carbon, thereby reducing greenhouse gas (GHG) emissions [1] [2] [15] [16]. Farmers will be motivated to apply biochar on their farms if these benefits can be demonstrated explicitly through various farming methods such as mixing the biochar with fertilizer and seed, applying through no till systems, uniform soil mixing, deep banding with plow, top-dressed, hoeing into the ground, applying compost and char on raised beds. However, the type of application of biochar to soil depends on the farming system, available machinery and labor [16]. Biochar has the potential to mitigate climate change because the inherent fixed carbon in raw biomass that would otherwise degrade to greenhouse gases is sequestered in soil for years. Assessments of the realistic

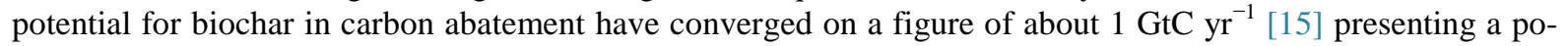
tential wedge for climate change mitigation. It can act as a soil amendment tool because of its beneficial impact on cation exchange capacity (CEC; 40 to $80 \mathrm{meq}$ per $100 \mathrm{~g}$, high surface area (51 to $900 \mathrm{~m}^{2} \cdot \mathrm{g}^{-1}$ ), which leads to increased soil pH and water holding capacity, and affinity for micro- and macro-plant nutrients [1] [9] [15]. The use of biochar as a soil amendment has been investigated since the early 1800's [1]. A number of studies have suggested that terrestrial application of biochar could effectively sequester carbon in soils and thus mitigate global warming [7] [17] reveals that applying biochar to agricultural soil is proposed for three reasons:

1) Only the soil seems to have a capacity sufficient to accommodate biochar at the scale relevant to the longterm mitigation of climate change;

2) There is potential for biochar to enhance soil function for agricultural productivity and thus offset the opportunity cost associated with its residual energy value, and;

3) The possible suppression of methane and nitrous oxide release would increase the value of biochar as a means to offset agricultural GHG emissions. In their study on biochar and its function in soil, [7] assert that a strategy to deploy biochar on a large scale would divert a portion of the existing global carbon flux that resides within managed ecosystems or to intercept enhanced net primary productivity production in the form of increased harvest or waste biomass. This reveals the great need and potential for technologies relevant for sustainable biochar production. Pyrolysis of the biomass feedstocks enables the biomass conversion to biochar whose subsequent application to soil is in a more stabilized form. When little or no oxygen is supplied, biochar is formed under the pyrolysis process, and with a controlled amount of supplied air, it is formed under the gasification process. The later optimizes the gaseous phase of biomass conversion while the former optimizes char yield. Biochar is currently the accepted term for pyrolysis-derived charcoal when used as a soil amendment [7]. The quest for a good biochar suitable for soil application is largely attributed by a number of social, technological as well as the environmental factors. It is the purpose of this work to review a state of the art technologies and how they are integrated in the biochar manufacturing niche.

\section{Properties of Biochar}

Characterization of biochar for proximate and ultimate analysis reveals the different biochar properties. Important physico-chemical properties include porosity, surface area and $\mathrm{pH}$ which all have an effect on its application to soil. Biochar is made up of elements such as carbon, hydrogen, sulphur, oxygen, nitrogen as well as minerals in the ash fraction. The properties of biochar will thus vary depending upon the production conditions and the nature of the feedstock used. For example, during the thermal oxidation of biomass to produce biochar, the inherent carbon is lost in the forms of $\mathrm{CO}_{2}, \mathrm{CO}, \mathrm{CH}_{4}$ and various hydrocarbons. Also, there is more cracking and devolatilization creating bigger pore holes inside the biochar if produced at higher temperatures. Results from [18] for biochar BET analysis revealed that samples with low surface area seem to have large, flat surfaces that have partial cracking, compared to the higher surface area samples, for which the cracking is further developed and there are more individually shaped spherical particles. Biochar surface area increases directly with treatment temperature due to increased volatilization of organic material, leaving a porous structure consisting of the mineral and carbon-based vascular tissue but if volatilization is allowed to continue beyond the optimum, the pores 
become wider and a drop in BET surface area may be observed [19]. Thus, a biochar with desirable properties can be deduced from both its proximate and ultimate analysis. The lower the $\mathrm{O} / \mathrm{C}$ and $\mathrm{H} / \mathrm{C}$ ratios, the higher is the loss of oxygen and hydrogen during the combustion process [20] producing a product richer in higher elemental carbon. The International Biochar Initiative (IBI) recommends a maximum value of 0.7 for the molar $\mathrm{H} / \mathrm{C}$ ratio [20] to distinguish biochar from biomass that has not been or only somewhat thermo-chemically altered. Thus suitable working conditions and technologies must be selected in order to produce a biochar of high quality.

\section{Small Scale Technologies for Biochar Production}

Technologies producing biochar are designed and optimized to produce char ahead of liquid tars and pyrotic gases (Table 1). The common processes include slow and fast pyrolysis, and the most successful approach for high-yield biochar production is via slow pyrolysis (Table 1). Under slow pyrolysis, a biochar yield between 25\% - 35\% can be reproducibly produced. During slow pyrolysis, the residence time of the feedstock is longer and the temperatures are lower than $700^{\circ} \mathrm{C}$. This allows all the volatile components to escape leaving a chary solid behind. Table 1 shows that a yield of 35\% biochar is feasible via slow pyrolysis. Such a yield may vary depending on the nature of the feedstock, reactor type as well as the degree of operating conditions optimization. [21] revealed that pyrolytic gasification is an example of indirectly heated processes which utilizes an external vessel to burn portion of the fuel and uses the heat to pyrolyze the biomass producing medium-energy gas with significant fraction of tars. Such a design has great prospects for modification to produce biochar because the movement of the ignition front leaves char behind. The current position of pyrolysis in the context of a range of other biomass conversion processes is shown in Figure 1.

As shown in Figure 1, fast pyrolysis processes aim at production of bio-oil and the amount of biochar formed is a small fraction of nearly $12 \%$ of the total biomass (Table 1 ). To obtain a high bio-oil yield, biomass fast pyrolysis needs to satisfy four conditions namely, a medium temperature $\left(450^{\circ} \mathrm{C}-600^{\circ} \mathrm{C}\right)$, high heating rate $(103$ $104 \mathrm{~K} / \mathrm{s})$, short vapor residence time $(<2 \mathrm{~s})$ and fast condensation of vapors [22]. This implies that although a series of biomass materials can be used to produce biochar, the yield largely depends on the method of production as well as the operating conditions. Such conditions include temperature, particle size, moisture content, feedstock type, nature and type of the reactor, and mode of operation. The small scale technologies available can be either manually operated or automatically run. In these technologies, it is possible to control some of the variables that affect the yield of biochar while it is not possible to directly control some operating conditions. The mode of operation also varies with reactors designed for either autothermal or allothermal mode.

\subsection{Autothermal Reactors}

Autothermal reactors provide the necessary heat of reaction by means of partial oxidation of the biomass within the reactor. The heat produced is sufficient to drive the endothermic reactions within the reactor to produce biochar, bio-oil and syngas [22]. Air is generally employed as the oxidation agent. The yield largely depends on the reactor design, operating conditions and physico-chemical properties of the biomass. Such designs include top lit updraft gasifiers (TLUG) [23], natural draft [24]. The TLUG is a "tar burning, char making" gasifier which has the advantage that tar is much lower, due to flaming pyrolysis of the biomass and the gases then passing

\begin{tabular}{|c|c|c|c|c|}
\hline Mode & Condition & Liquid (bio-oil) & Solid (biochar) & Gas (syngas) \\
\hline Fast pyrolysis & $\begin{array}{l}\text { Moderate temperature }\left(\sim 500^{\circ} \mathrm{C}\right) \\
\text { Short vapor residence time }(<2 \mathrm{~s})\end{array}$ & $75 \%$ ( $25 \%$ water) & $12 \%$ & $13 \%$ \\
\hline Intermediate pyrolysis & $\begin{array}{l}\text { Low-moderate temperature } \\
\text { Moderate hot vapor residence time }\end{array}$ & $50 \%$ ( $50 \%$ water) & $25 \%$ & $25 \%$ \\
\hline Slow pyrolysis & $\begin{array}{l}\text { Low-moderate temperature } \\
\text { Long residence time }\end{array}$ & $30 \%$ (70\% water) & $35 \%$ & $35 \%$ \\
\hline Gasification & $\begin{array}{l}\text { High temperature }\left(>800^{\circ} \mathrm{C}\right) \\
\text { Long vapor residence time }\end{array}$ & $5 \% \operatorname{tar}$ (55 water) & $10 \%$ & $85 \%$ \\
\hline
\end{tabular}




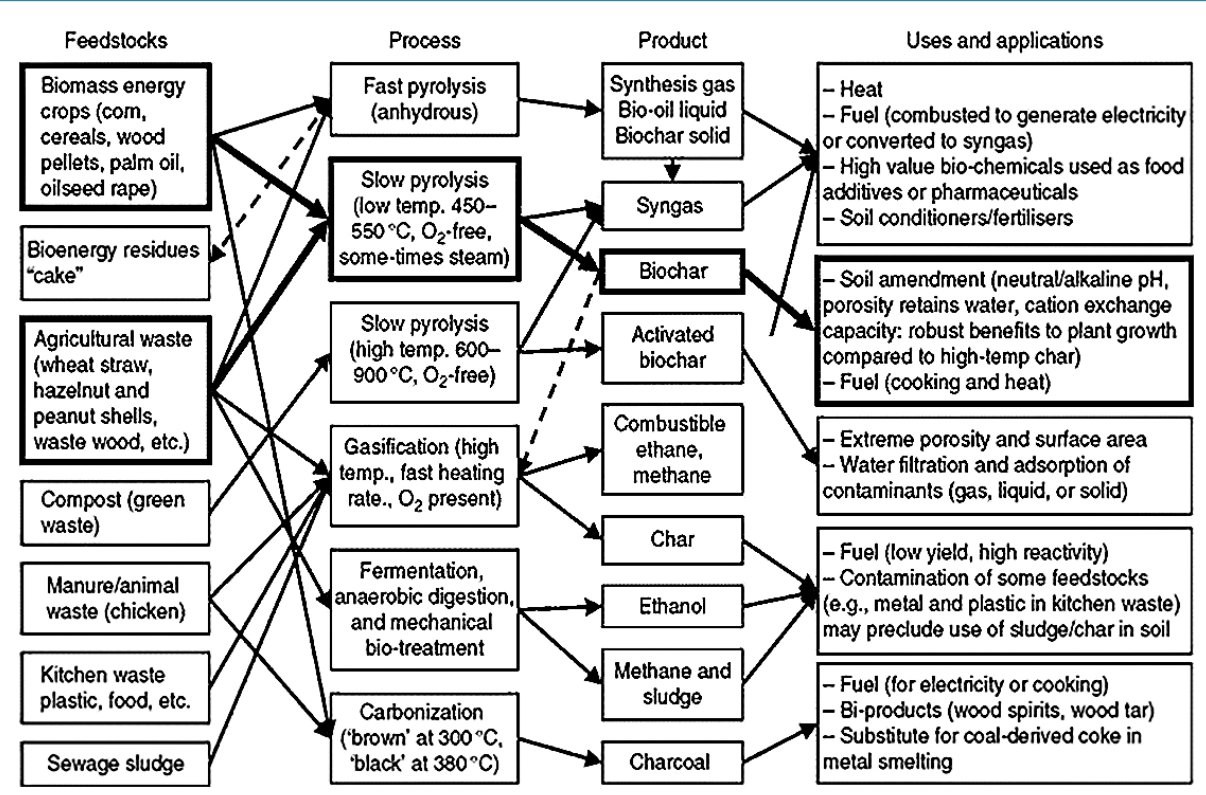

Figure 1. Biochar and other products of thermal conversion of biomass according to available technologies and feedstocks [7].

through a layer of charcoal on the top [23]. TLUG are easily adaptable and can be used for small scale char production because of their ease of operation, simple technology with ease of fabrication, ease of operation as well as the ability to generate a substantial char yield [25].

\subsection{Allothermal Reactor}

Allothermal reactors require the heat-of-reaction from an external heat source into the reactor. External heat sources include biomass as well as non-renewable fuels. Allothermal reactors have not found wide use for smallscale application because they are not easy to implement due to larger investment costs [22].

\section{Commonly Used Technologies for Biomass Pyrolysis}

[26] proposed the following technologies for biomass pyrolysis which have been extensively used although their application is limited due to their respective drawbacks hence a quest for more unlimited applications. Amongst these conventional pyrolysis units include:

- Fixed beds: These have been used for the traditional production of charcoal. They are poor in heat and mass transfer because the bed is stationary in one position and there is no uniform mixing inside the reactor.

- Fluidized beds: These reactors are more effective with gasification reactions because there is effective heat and mass transfer. Within fluidized bed reactors, the biomass is mixed with a hot sand bed fluidized by a gas which keeps the mixture rotating within the reactor. The attrition between biomass particles and sand particles doesn't make fluidized beds a better choice for biochar production because there is a higher carbon conversion to gases than to solid char.

- Augers: In this technology, hot sand and biomass particles are fed at one end of a screw which mixes the sand and biomass and conveys them along. This process works best when pyrotic gases are the major product because it avoids the dilution of the pyrotic products with the carrier gases. Reheating of sand must be done in a separate vessel and mechanical reliability is a concern.

- Ablative technologies: During ablative processes, biomass particles are moved at high speed against a hot metal surface. Ablation of any char forming at a particle's surface maintains a high rate of heat transfer. This can be achieved by using a metal surface spinning at high speed within a bed of biomass particles, which may present mechanical reliability problems but prevents any dilution of the products.

- Rotating cone: Pre-heated hot sand and biomass particles are introduced into a rotating cone. Due to the rotation of the cone, the mixture of sand and biomass is transported across the cone surface by centrifugal force.

- Circulating fluidized beds: Biomass particles are introduced into a circulating fluidized bed of hot sand. Gas, 
sand and biomass particles move together, with the transport gas usually being a recirculated product gas, although it may also be a combustion gas. High heat transfer rates from sand ensure rapid heating of biomass particles and ablation stronger than with regular fluidized beds. A fast separator separates the product gases and vapors from the sand and char particles. The sand particles are reheated in a fluidized burner vessel and recycled to the reactor. Although this process can be easily scaled up, it is rather complex and the products are much diluted, which greatly complicates the recovery of the liquid products.

- Chain grate: Dry biomass is fed onto a hot $\left(500^{\circ} \mathrm{C}\right)$ heavy cast metal grate or apron which forms a continuous loop. A small amount of air aids in heat transfer and in primary reactions for drying and carbonization. Volatile products are combusted for process and boiler heating.

\subsection{Processes and Parameters Affecting Biochar Production in Stoves}

[27] revealed that there is indeed tremendous potential for both localized "intensive" benefits and also global "extensive" advantages emanating from scaled up carbon-financed ICS (improved cook stove) programs. [28] reported that a lot of effort has been devoted over the past decades to develop improved stoves, which reduce fuel use by $40 \%$ to $50 \%$ with equivalent reduction in associated emissions and are now in production at a value greater than 100,000 units per year. [18] proposed an alternative method of biochar production with a much simpler and accessible process design: a gasification cook stove where biochar can be created under atmospheric conditions because the cook stove is designed so that continuous combustion is kept spatially separated from where pyrolysis of the feedstock occurs. Fan-assisted stoves require an electricity source such as PV-powered batteries [29], the grid or through the use of thermo-electric (TE) devices which convert some of the heat generated by the stove into electricity [28] though TE devices require considerable further development and cost reduction. One advantage with producing biochar in cooking stoves is that it can run under atmospheric conditions and does not require the use of any inert gas. It can be scaled up and configured to run with a continuous stream of feedstock and has a greater throughput than batch methods [30]. For biochar to be produced in improved autothermal TLUD cooking stoves, a defined amount of sub stoichiometric air is supplied which induces a moving counter current bed whose combustion characteristics are greatly influenced by the amount of air supplied. The amount of air has a direct effect on the temperature gradient inside the reactor, the movement of the fuel bed, reaction kinetics and the total gasification time. The practitioner refers to the reaction kinetics as the specific gasification rate which is defined as the rate of mass loss per unit area and unit time. The initial heat is supplied by firing the fuel on top of the bed with the combustion zone moving downwards in presence of the continuous oxygen supplied. The heat generated within the combustion zone is transferred by conduction, convection and radiation throughout the stove. This allows for drying, pyrolysis, and gasification of biomass as well as removal of volatile gases from the stove through forced air supply. Because the heterogeneous char oxidation is relatively slow and the oxygen supplied is limited, carbonized particles (char) remain behind the ignition front. When the combustion zone reaches the grate, all original biomass has been pyrolyzed and from now on only char oxidation takes place turning char to ash if supply of oxygen continuous. Hence, the reactor is typically stopped at this stage to avoid the unwanted char oxidation during biochar production.

\subsubsection{The Chemistry of Gasification and the Effect of Production Conditions on Biochar}

The major processes that take place during gasification of biomass include drying at nearly $105^{\circ} \mathrm{C}$ where water is driven off. The dried material undergoes pyrolysis as shown in Equation (2-1) through which volatile components are released [31]. Subsequently, the combustion process occurs as carbon matter reacts with oxygen to form $\mathrm{CO}_{2}$ and $\mathrm{CO}$, shown in Equations (2-3), (2-4) respectively which provides heat for the subsequent gasification reactions. Letting $\mathrm{C}$ represent a carbon-containing compound, the gasification process occurs as the char reacts with $\mathrm{CO}_{2}$ and steam to produce $\mathrm{CO}$ and $\mathrm{H}_{2}$ (Equations (2-5), (2-6)) respectively. In addition, the reversible gas phase water gas shift reaction in Equation (2-10) reaches equilibrium very fast at temperatures of $800^{\circ} \mathrm{C}$. This balances the concentrations of $\mathrm{CO}, \mathrm{CO}_{2}$ and $\mathrm{H}_{2}$ within the system. Generally, a small amount of air (Equation (2-8)) introduced into the reactor allows some of the organic material to be burned to produce $\mathrm{CO}$ and energy which drives the process that converts further organic material to $\mathrm{H}_{2}$ and additional $\mathrm{CO}_{2}$. Consequent reactions occur when the formed $\mathrm{CO}$ and residual water from the organic material react to form $\mathrm{CH}_{4}$ and excess carbon dioxide (Equation (2-11)). Details of these reactions are illustrated in Table 2. The kinetics of these reactions depends on the operating conditions under play. This subsequently affects the quality and quantity of the 
Table 2. Gasification reactions [43].

\begin{tabular}{lcc}
\hline Nature of reaction & Reaction & Reaction number \\
\hline Pyrolysis & Biomass + heat $+\mathrm{ir} \leftrightarrow \mathrm{Char}+\mathrm{H}_{2}+\mathrm{CO}_{2}+\mathrm{CH}_{4}+\mathrm{CO}+\mathrm{C}_{\mathrm{m}} \mathrm{H}_{\mathrm{n}}+\mathrm{H}_{2} \mathrm{O}+\mathrm{N}_{2}+\mathrm{O}_{2}$ & $(2-1)$ \\
Tar cracking & $\mathrm{C}_{\mathrm{m}} \mathrm{H}_{\mathrm{n}} \rightarrow \mathrm{H}_{2}+\mathrm{CO}+\mathrm{CO}_{2}+\cdots$ & $(2-2)$ \\
Heterogeneous reactions & $\mathrm{C}+1 / 2 \mathrm{O}_{2} \rightarrow \mathrm{CO}$ & $(2-4)$ \\
$\mathrm{C}+\mathrm{O}_{2} \rightarrow \mathrm{CO}_{2}$ & $(2-5)$ \\
$\mathrm{C}+\mathrm{CO}_{2} \rightarrow 2 \mathrm{CO}$ & $(2-6)$ \\
$\mathrm{C}+\mathrm{H}_{2} \mathrm{O} \rightarrow \mathrm{CO}+\mathrm{H}_{2}$ & $(2-7)$ \\
$\mathrm{C}+2 \mathrm{H}_{2} \rightarrow \mathrm{CO}+\mathrm{CH}_{4}$ & $(2-8)$ \\
$\mathrm{CO}+1 / 2 \mathrm{O}_{2} \rightarrow \mathrm{CO}_{2}($ combustion $)$ & $(2-9)$ \\
$\mathrm{H}_{2}+1 / 2 \mathrm{O}_{2} \rightarrow \mathrm{H}_{2} \mathrm{O}$ & $(2-10)$ \\
\hline
\end{tabular}

gasification products. Production conditions influence char properties, fixed carbon as well as its stability in the soil [32]. A good biochar produced under optimal conditions should be recalcitrant in the soil for longer residence times [33]. Such conditions include temperature [32] [34]-[36] nature of feedstocks [37], particle size [38], heating rate [35], heating source [39], reactor type [40], gasification time [41], equivalence ratio [42] as well as pressure [31].

$\mathrm{H}_{2}$ (Equation (2-10)), and $\mathrm{CO}$ (Equation (2-11)) and a significant amount of $\mathrm{CH}_{4}$ (Equation (2-13)), $\mathrm{CO}_{2}$ (Equation (2-10)), $\mathrm{H}_{2} \mathrm{O}$ (Equation (2-13)), and $\mathrm{N}_{2}$ (Equation (2-1)) are always present in the producer gas (Equation (2-1)), together with organic (tar) and inorganic $\left(\mathrm{H}_{2} \mathrm{~S}, \mathrm{HCl}, \mathrm{NH}_{3}\right.$, and alkali metals) impurities and particulates [44]. The tars formed are organic impurities comprising a range of low to high molecular weight hydrocarbons which condense under ambient conditions. The product content of these undesirable contaminants can be reduced by careful control of the operating conditions (temperature, biomass heating rate, etc.), appropriate reactor design and suitable gas conditioning systems [45].

\subsubsection{Effect of Feedstock Type on Biochar Yield}

Biomass consists of three major components (hemicellulose, cellulose, and lignin) together with trace amount of extractives and minerals [46]. Due to these constituents, which vary in composition according to biomass type, the pyrolysis and gasification behavior of lignocellulosic biomass (LB) depends upon these main components of cellulose, xylan (hemicelluloses), and lignin. Proportions of hemicellulose, cellulose, and lignin content appear to influence the ratio of volatile carbon in oil and gas and the proportion of carbon stabilized in biochar [7]. In Table 3, varying char yields were obtained from different biomass species because of the difference in composition of the biomass feedstocks. The higher the lignin content (which normally corresponds to the lower content of cellulose), the lower the pyrolysis weight loss [47]. Feedstocks with high lignin content generate high yields of biochar when pyrolyzed at temperatures of approximately $500^{\circ} \mathrm{C}$ [48] [49].

\subsubsection{Effect of Temperature on Biochar Yield and Carbon Stability}

In a study conducted by [53] lab-scale pyrolysis to produce biochar at three temperatures between $350^{\circ} \mathrm{C}$ and $550^{\circ} \mathrm{C}$ from selected feedstock (pine, mixed larch and spruce chips, softwood pellets), showed that despite an increase in the stability of biochar with increasing pyrolysis temperature, the yield of stable biochar is nearly independent of temperature. These results indicate that from the point of view of sequestering maximum amount of carbon per unit of feedstock, low-temperature conversion processes might perform as effectively as higher 
Table 3. Effect of feedstock type on char yield.

\begin{tabular}{|c|c|c|c|c|c|c|c|}
\hline $\begin{array}{l}\text { Agricultural } \\
\text { Waste Type }\end{array}$ & $\begin{array}{l}\text { Lignin } \\
\text { Content \% }\end{array}$ & $\begin{array}{c}\text { Hemicellulose } \\
\text { (Xylan) Content \% }\end{array}$ & $\begin{array}{l}\text { Cellulose } \\
\text { Content \% }\end{array}$ & $\begin{array}{c}\text { Ash } \\
\text { Content \% }\end{array}$ & Biochar Yield \% & \multicolumn{2}{|c|}{ Fixed Carbon \% Reference } \\
\hline Red oak & 19.58 & 20.45 & 30.02 & $2.24 \pm 0.04$ & $\begin{array}{c}\text { Cellulose char } 4.45 \% \text {, xylan char } \\
1.89 \% \text {, lignin char } 41.43 \%\end{array}$ & $20.55 \pm 0.13$ & {$[50]$} \\
\hline $\begin{array}{l}\text { Empty fruit } \\
\text { bunch }\end{array}$ & 24 & 43 & 26 & na & $\begin{array}{c}\text { Hemicellulose char (20 wt\%), } \\
\text { lignin char } 60 \% \text {, } \\
\text { cellulose char } 7 \mathrm{wt} \%\end{array}$ & na & {$[46]$} \\
\hline Sawdust & 28.9 & 29.3 & 41.8 & 0.6 & $13.8 \%$ & na & {$[51]$} \\
\hline Willow & 19.6 & na & na & 1.3 & 20.9 & na & {$[52]$} \\
\hline Switch grass & 8.6 & na & na & 4.3 & 24.7 & na & {$[52]$} \\
\hline Straw & 7.5 & na & na & 6.3 & 29.9 & na & {$[52]$} \\
\hline Reed canary grass & 9.3 & na & na & 5.1 & 24.4 & na & {$[52]$} \\
\hline Rice husk & 24.4 & 28.6 & 28.6 & 17.9 & $\sim 30$ & 9.3 & [47] \\
\hline Rice straw & 22.3 & 35.7 & 32.0 & 10.1 & $\sim 22$ & 15.2 & [47] \\
\hline Corncob & 15.0 & 31.0 & 50.5 & 0.9 & $\sim 10$ & 16.2 & [47] \\
\hline
\end{tabular}

na: not available.

temperature pyrolysis processes. By using an accelerated ageing technique to determine the stability of biochar, [54] showed that the fraction of recalcitrant carbon in biochar increases with increasing pyrolysis temperature. This means that biochar exposed to higher pyrolysis temperatures contains a higher proportion of the stable fraction than biochar produced at low temperatures. Since the primary objective of biochar is to store carbon, it is the yield of carbon contained in the solid product that is important, rather than the yield of biochar itself. Reporting experimental results from pyrolysis experiments aimed at biochar production only in terms of biochar yields without data on fixed organic carbon yields is not sufficient as it does not provide a true picture of the effectiveness of the process in terms of carbon sequestration potential. In a different study by [36], Conocarpus sp. wastes were pyrolyzed at different temperatures $\left(200^{\circ} \mathrm{C}-800^{\circ} \mathrm{C}\right)$ to investigate their impact on characteristics and chemical composition of biochars. As pyrolysis temperature increased, ash content, $\mathrm{pH}$, electrical conductivity, basic functional groups, carbon stability, and total content of $\mathrm{C}, \mathrm{N}, \mathrm{P}, \mathrm{K}, \mathrm{Ca}$, and $\mathrm{Mg}$ increased while biochar yield, total content of $\mathrm{O}, \mathrm{H}$ and $\mathrm{S}$, unstable form of organic $\mathrm{C}$ and acidic functional groups decreased while the ratios of $\mathrm{O} / \mathrm{C}, \mathrm{H} / \mathrm{C},(\mathrm{O}+\mathrm{N}) / \mathrm{C}$, and $(\mathrm{O}+\mathrm{N}+\mathrm{S}) / \mathrm{C}$ tended to decrease with temperature. Similarly, these results suggested that biochar pyrolyzed at high temperature may possess a higher carbon sequestration potential when applied to the soil compared to that obtained at low temperature. Furthermore, [32] conducted a study to investigate the influence of pyrolysis temperature on production of wastewater sludge biochar and evaluated the properties required for agronomic applications through pyrolysis in laboratory scale reactor and found that by increasing the pyrolysis temperature (over the range from $300^{\circ} \mathrm{C}$ to $700^{\circ} \mathrm{C}$ ) the yield of biochar decreased. The biochar produced at low temperature was acidic whereas at high temperature it was alkaline in nature. Subsequently, the concentration of nitrogen was found to decrease while micronutrients increased with increasing temperature. All authors agreed that biochar yield decreases linearly with pyrolysis temperature. The effect of operating conditions on the quality of biochar produced is further detailed in Table 4.

\subsubsection{Effect of Pressure on Biochar Yield}

During an experiment conducted by [58] a factorial design of experiments was used to investigate the effect of absolute pressure (in the range $0.1-1.5 \mathrm{MPa}$ ) and peak temperature (in the range $400^{\circ} \mathrm{C}-550^{\circ} \mathrm{C}$ ) on the pyrolysis behavior of two-phase olive mill wastes (TPOMW). From results of regression analyses, they concluded that 1) biochar yield from pyrolysis of TPOMW decreases when both peak temperature and pressure increases; 2), an increase of both peak temperature and pressure results in a higher fixed carbon yield; and 3), a significant increase of the overall devolatilization rate was observed for experiments conducted at intermediate pressure values (0.8 MPa). The effect of pressure on biochar yield and other gasification products are further detailed in the 
Table 4. Effect of operating conditions on the char yield and stability.

\begin{tabular}{|c|c|c|c|}
\hline Study objective & Operating condition & Feedstock type & Observation \\
\hline $\begin{array}{l}\text { To determine the } \\
\text { influence of production } \\
\text { conditions on the yield } \\
\text { and environmental } \\
\text { stability of biochar }\end{array}$ & 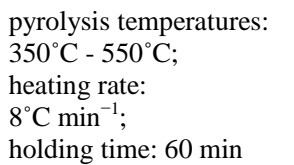 & $\begin{array}{l}\text { pine, mixed } \\
\text { larch and } \\
\text { spruce chips, } \\
\text { softwood pellets }\end{array}$ & $\begin{array}{l}\text { - biochar stability increases with increasing } \\
\text { pyrolysis temperature; } \\
\text { the yield of biochar decreases with the pea } \\
\text { pyrolysis temperature }\end{array}$ \\
\hline
\end{tabular}

Reference

- at $600^{\circ} \mathrm{C}$ biochar has highest fixed carbon content, FC (80.7\%), carbon (73.8\%), higher heating value, $\mathrm{HHV}\left(30.3 \mathrm{MJ} \cdot \mathrm{kg}^{-1}\right)$ and lowest

temperatures: $400^{\circ} \mathrm{C}$,

To investigate the effect of pyrolysis temperature and heating rate on

$4500^{\circ} \mathrm{C}$

$500^{\circ} \mathrm{C}, 550^{\circ} \mathrm{C}$ and $600^{\circ} \mathrm{C}$ heating rates: $10^{\circ} \mathrm{C}, 30^{\circ} \mathrm{C}$ biochar from pyrolysis of and $50^{\circ} \mathrm{C} \mathrm{min}-1$ safflower seed press cake $20 \mathrm{~g}$ of biomass samples (SPC) safflower seed press cake volatile matter content, VM (9.80\%);

- biochars had low BET surface areas (1.89 - $4.23 \mathrm{~m}^{2} / \mathrm{g}$ ) containing predominantly aromatic compounds;

- biochar yield decreased linearly with increasing temperature;

- $\quad$ increase in heating rate reduced VM, FC and BET surface area but had no clear effect on HHV, elemental composition and $\mathrm{pH}$

To determine the physical and thermochemical temperature: characterization of rice husk char as a potential biomass energy source $200^{\circ} \mathrm{C}-650^{\circ} \mathrm{C}$ heating rate: $50^{\circ} \mathrm{C}$ holding time: $60 \mathrm{~min}$

- temperature: $1200^{\circ} \mathrm{C}$

- rice husk particles injected into the centre of the reactor at

Characterization of char from rapid pyrolysis of rice husk

Characterization of biochars to evaluate recalcitrance and agronomic performance extremely high heating rates $\left(\approx 1 \times 104^{\circ} \mathrm{C} / \mathrm{s}\right)$, rice husk short residence times under a $\mathrm{N}_{2}$ environment at atmospheric pressure

- $\quad$ pyrolyzing the feedstocks in $50^{\circ} \mathrm{C}$ increments from $300^{\circ} \mathrm{C}$ to $600^{\circ} \mathrm{C}$

- holding at the target temperature: 15 - 20 $\min$

- $\quad$ about $3 \mathrm{~kg}$ of feedstock manually placed into main chamber purged with $\mathrm{N}_{2}$ while running the mixer

manure,

hazelnut, rice husk

- $400^{\circ} \mathrm{C}$ the optimum temperature with char having moderate $\mathrm{HHV}$;

- $\quad$ order of reaction in combustion zone was $\sim 1$, the activation energy $73.4 \mathrm{~kJ} / \mathrm{mol}$ with pre-exponential factor $4.97 \times 10^{4} \mathrm{~min}^{-1}$

- based on SEM, pore surface of char particle became increasingly rough in the middle of pyrolysis;

- the surface area of char increased with pyrolysis process to a maximum value of $56.95 \mathrm{~m}^{2} / \mathrm{g}$ at pyrolysis reaction ratio $(\mathrm{Rp}=0.90)$;

- the $\mathrm{H} / \mathrm{C}, \mathrm{O} / \mathrm{C}$ and N/C ratios of the char changed with different trends when the pyrolysis reaction ratio increased;

- FTIR studies indicated a gradual decrease in the intensities of $\mathrm{OH}, \mathrm{C}-\mathrm{H}$ and $\mathrm{C}-\mathrm{O}$ stretches with pyrolysis process

- biochar ash contents varied from $0.4 \%$ to $88.2 \%$, VM from $13.2 \%$ to $70.0 \%$, and fixed carbon from $0 \%$ to $77.4 \%(\mathrm{w} / \mathrm{w})$;

- $\quad$ pyrolysis temperature and FC increase proportionally for low-ash biochars, but decrease for biochars with > $20 \%$ ash;

orn, dairy

oak, pine and

poultry manure

- $\quad$ nitrogen recovery varied depending on feedstock used at a pyrolysis temperature of $600^{\circ} \mathrm{C}$;

- at $600^{\circ} \mathrm{C}$, fixed carbon production ranged from no enrichment in poultry biochar to a 10 -fold increase in corn biochar;

- woody feedstock demonstrated the greatest versatility with $\mathrm{pH}$ values ranging from 4 to 9

Table 5. The major observations reveal that using smaller particles, operating under high pressure and at high peak temperature is the best way to maximize the pyrolysis gas production but not the char yield. The absolute pressure decreased the tar content in the producer gas at the outlet of a secondary cracking reactor [59].

\subsubsection{Effect of Reactor Type on Yield and Biochar Properties}

The nature and type of the reactor has an effect on the yield and the properties of the biochar produced. [62] conducted a study that compared slow pyrolysis and microwave (MW) pyrolysis of two different feedstocks 
Table 5. Effect of pressure on biochar yield.

\begin{tabular}{|c|c|c|c|c|c|}
\hline Biomass type & Process type & Yield & Operating conditions & Main findings & Reference \\
\hline $\begin{array}{l}\text { Olive mill } \\
\text { waste } \\
\text { water } \\
\text { (OMW) }\end{array}$ & $\begin{array}{l}\text { hydro } \\
\text { thermal } \\
\text { carbonization } \\
\text { (HTC) }\end{array}$ & $\sim 30 \%$ & $\begin{array}{l}\text { - } \quad \text { catalyst: citric acid; } \\
\text { - } \quad \text { temperature: } 180^{\circ} \mathrm{C} \\
\text { or } 220^{\circ} \mathrm{C} \text {; } \\
\text { - } \quad \text { residence time: } 14 \mathrm{~h} \text {; } \\
\text { pressures: } 9 \text { bar }\left(180^{\circ} \mathrm{C}\right) \\
\text { and } 24 \text { bar }\left(220^{\circ} \mathrm{C}\right)\end{array}$ & $\begin{array}{l}\text { - the organic carbon content of the } \\
\text { biochar is enhanced with increasing } \\
\text { HTC temperature and pressure; } \\
\text { mass balance considerations confirm that } \\
\text { the yield of biochar is associated with a } \\
\text { low fraction of carbohydrates in OMW }\end{array}$ & {$[60]$} \\
\hline $\begin{array}{l}\text { Two-phase olive } \\
\text { mill waste } \\
\text { (TPOMW) }\end{array}$ & TGA & $\sim 22.4 \%$ & $\begin{array}{l}\text { - } \quad \text { pressure: } 0.1-1.5 \mathrm{MPa} \text {; } \\
\text { peak temperature: } \\
400^{\circ} \mathrm{C}-550^{\circ} \mathrm{C} \text {; } \\
\text { - } \quad \text { heating rate: } 5 \mathrm{~K} \cdot \mathrm{min}^{-1}\end{array}$ & $\begin{array}{l}\text { - biochar yield from pyrolysis of TPOMW } \\
\text { decreased when both peak temperature } \\
\text { and pressure increased; } \\
\text { an increase of both peak temperature and } \\
\text { pressure results in a higher fixed-carbon yield } \\
\text { and devolatilization rate }\end{array}$ & {$[58]$} \\
\hline Sunflower husks & $\begin{array}{l}\text { thermochemical } \\
\text { liquefaction }\end{array}$ & $\begin{array}{c}574 \\
g_{\text {char }} \cdot \mathrm{kg}^{-1} \\
\text { husks }\end{array}$ & $\begin{array}{l}\text { - } \quad \text { temperature: } 280^{\circ} \mathrm{C} \text {; } \\
\text { - } \quad \text { feed rate } 30 \mathrm{~g} \cdot \mathrm{kg}^{-1} \text {; } \\
\text { solvent: distilled water, } \\
\text { methanol, ethanol, } \\
\text { isopropanol and n-butanol }\end{array}$ & $\begin{array}{l}\text { - HHV of the biochars were higher than that } \\
\text { of the feedstock; } \\
\text { biochars compared favorably with coal } \\
\text { on a Van Krevelen diagram; } \\
\text { at temperatures below } 280^{\circ} \mathrm{C} \text {, the charring } \\
\text { of the biomass is not complete, with some } \\
\text { of the cell wall lignin still intact }\end{array}$ & {$[61]$} \\
\hline $\begin{array}{l}\text { Vine } \\
\text { shoots-derived } \\
\text { biochar }\end{array}$ & $\begin{array}{l}\text { laboratory-scale } \\
\text { fixed-bed } \\
\text { slow pyrolysis }\end{array}$ & na & $\begin{array}{l}\text { - } \quad \text { heating rate: } \sim 5 \mathrm{~K} \cdot \mathrm{min}^{-1} \text {; } \\
\text { - } \quad \text { pressure: } 0.1-1.1 \mathrm{Mpa} \text {; } \\
\text { - } \quad \text { temperature: } \\
\quad 400^{\circ} \mathrm{C}-600^{\circ} \mathrm{C}\end{array}$ & $\begin{array}{l}\text { - particle size the most significant factor in } \\
\text { determining the potential stability of biochars; } \\
\text { - } \text { operating at higher peak temperatures leads to } \\
\text { the production of more stable materials; } \\
\text { - the absolute pressure decreased the tar } \\
\text { content in the producer gas; } \\
\text { - no statistically significant effects of increasing } \\
\text { pressure on the aromaticity of biochar }\end{array}$ & [59] \\
\hline
\end{tabular}

(willow chips and straw), with particular focus on physical properties of the resulting biochars and their relation to biochar soil function. In these experiments, slow pyrolysis laboratory units at the University of Edinburgh and the MW pyrolysis units at the University of York were used to produce biochar from identical feedstock under a range of temperatures. Physical properties and stability of produced biochar from both systems were then analyzed and compared. The results showed that using MW, pyrolysis can occur even at temperatures of around $200^{\circ} \mathrm{C}$, while in the case of conventional heating a higher temperature and residence time was required to obtain similar results. Researchers revealed that the low pyrolysis temperature in MW is possible due to the differences in the temperature of decomposition, heating rates and requirement for feedstock pre-processing (e.g. shredding or drying) [63]. Microwave heating offers several advantages over conventional heating, as it is often more controllable [64]. The difference in attaining pyrolysis temperatures between the different reactors can subsequently produce chars of different properties as well as the yield. This is because of the difference in the rates of thermal decomposition. Detailed results on gasification products from different production methods are shown in Table 6. In general, the yield and biochar characteristics are dependent on the maximum attainable temperatures within the biochar production system. Systems with high energy efficiency have the potential to produce a good biochar.

\subsubsection{Effect of Moisture Content on Biochar Yield}

The quality of the fuel depends on the moisture content, which affects the heating value [68]. The moisture content in the biomass is one of the important parameters that affects the performance of the gasifier through the variation in the producer gas composition and conversion efficiency [69]. The amount of moisture content may be due to the inherent water content in the raw biomass specie or due to prevailing weather conditions. The amount of moisture present leads to loss of heat (quenching) as a matter of evaporating off the water and super heating of the vapor. A moisture content higher than $67 \%$ (on dry basis) makes the product gas too lean for ignition [21]. The presence of moisture during gasification reduces the thermal energy and subsequently forms more 
Table 6. Effect of pressure on biochar yield.

\begin{tabular}{|c|c|c|c|}
\hline Study & Production method & Main findings & Reference \\
\hline $\begin{array}{l}\text { MW and slow } \\
\text { pyrolysis biochar }\end{array}$ & $\begin{array}{l}\text { slow pyrolysis and } \\
\text { MW pyrolysis }\end{array}$ & $\begin{array}{l}\text { - MW assisted pyrolysis starts at } 200^{\circ} \mathrm{C} \text {, while in case of conventional } \\
\text { heating a higher temperature and residence time was required to } \\
\text { obtain similar results }\end{array}$ & {$[62]$} \\
\hline $\begin{array}{l}\text { Production of solid } \\
\text { biochar fuel from } \\
\text { waste biomass }\end{array}$ & HTC & $\begin{array}{l}\text { - } \quad \text { energy density of biochar increased with increasing hydrothermal } \\
\text { temperature } \\
\text { - most hemicellulose and cellulose were decomposed below } 250^{\circ} \mathrm{C} \\
\text { while the degradation of lignin only occurs at higher temperatures } \\
\text { - biochar yield decreased rapidly with increasing temperature }\end{array}$ & {$[61]$} \\
\hline $\begin{array}{l}\text { Effects of feedstock } \\
\text { type, production method, } \\
\text { and pyrolysis temperature } \\
\text { on biochar and } \\
\text { hydrochar properties }\end{array}$ & slow pyrolysis & $\begin{array}{l}\text { - } \quad \text { the production method showed strong effect on biochar properties. } \\
\text { higher pyrolysis temperatures produced higher thermal stability } \\
\text { biochars } \\
\text { biochar yields decreased with increasing temperature and when peak } \\
\text { temperature rose from } 200^{\circ} \mathrm{C} \text { to } 600^{\circ} \mathrm{C} \text {, carbon contents increased } \\
\text { and oxygen and hydrogen contents decreased }\end{array}$ & [65] \\
\hline $\begin{array}{l}\text { Comparison of kiln-derived } \\
\text { and gasifier-derived biochars } \\
\text { as soil amendments } \\
\text { in the humid tropics }\end{array}$ & $\begin{array}{l}\text { kiln-produced } \\
\text { biochar }\end{array}$ & $\begin{array}{l}\text { - highest estimated temperature reached inside the kiln was } 400^{\circ} \mathrm{C} \text { and } \\
600^{\circ} \mathrm{C} \text { at the top and between } 600^{\circ} \mathrm{C} \text { and } 800^{\circ} \mathrm{C} \text { at the bottom } \\
\text { biochar yields were } 140-290 \mathrm{~g} \cdot \mathrm{kg}^{-1} \text { of the initial biomass weight for } \\
\text { eucalyptus, } 240-250 \mathrm{~g} \cdot \mathrm{kg}^{-1} \text { for maize cobs, } 450-490 \mathrm{~g} \cdot \mathrm{kg}^{-1} \text { for rice } \\
\text { husks, } 360-430 \mathrm{~g} \cdot \mathrm{kg}^{-1} \text { for coffee husks, and } 290-320 \mathrm{~g} \cdot \mathrm{kg}^{-1} \text { for } \\
\text { groundnut shells }\end{array}$ & {$[66]$} \\
\hline $\begin{array}{l}\text { Production and } \\
\text { characterization of bio-oil and } \\
\text { biochar from rapeseed cake }\end{array}$ & fixed bed pyrolysis & $\begin{array}{l}\text { - } \mathrm{H} / \mathrm{C}: 0.47, \mathrm{O} / \mathrm{C}: 0.27, \mathrm{AC}: 17.6 \% \text {, VM: } 18.7 \%, \mathrm{FC}: 63.7 \% \\
\text { - } \quad \text { biochar obtained are carbon rich, with high heating value and } \\
\text { relatively pollution-free potential solid biofuel }\end{array}$ & {$[67]$} \\
\hline
\end{tabular}

$\mathrm{CO}_{2}$ because the water gas shift reaction is favored at lower temperatures. This leads to formation of low calorific value gas as more $\mathrm{CO}$ is consumed while more $\mathrm{CO}_{2}$ is formed. The presence of high moisture during biochar formation would lower the temperatures for biochar producing char with low fixed carbon. As detailed in Table 7, the presence of high moisture content increases biomass fuel density which makes biomass transportation quite difficult.

\subsubsection{Effect of Equivalence Ratio on Biochar Yield}

The ratio of actual air flow to the theoretical airflow needed for stoichiometric combustion of the biomass is referred to as equivalence ratio (ER), which indicates the extent of partial combustion [43]. The process rates are classified into three successive regimes depending on the air flow rate: Oxygen-limited, reaction-limited and extinction by convection regimes [72]. The propagation of the ignition front is controlled by the amount of oxygen and the process rates are linearly proportional to the air flow rate. The process rates are limited by the reaction rate of the fuel in the reaction-limited regime. As the ER increases, the convective cooling of particles around the ignition front slows down the process and finally causes extinction of the flame [42]. To ensure the high temperature for gasification, air/oxygen is usually used as agent [39]. [73] asserts that gasification requires moving significantly lower quantity of air or oxidizer per unit weight of fuel based on the optimum operating range of 0.2 to 0.4 air ER as opposed to combustion which occurs around the stoichiometric region, typically at plus or minus $2 \%$ excess air. The amount of air supplied per unit mass of dry fuel can determine if the process condition or the stoichiometry of reaction is at or near the combustion range or within the optimum gasification range, it also determines the propagation of reaction front throughout fuel bed as well as determine the quality and quantity of gasification products. Results obtained by [74] performed using a cyclone gasifier concept with biomass micron fuel revealed that higher ER led to higher gasification temperature and contributed to high $\mathrm{H}_{2}$-content, but too high ER lowered fuel gas content and degraded fuel gas quality. The effect of ER on biomass gasification is detailed in Table 8. Authors reported an increase in gas formation as ER increases but the effect of ER on char properties is still poorly understood. Using gasification has significant processing advantages; it can be carried out in normal atmospheric conditions, eliminating the use of inert gas, is more amenable to scale up and provides heat that can be used to generate power and/or help recoup processing costs [18]. 
Table 7. Effect of moisture content on the yield of gasification products.

\begin{tabular}{|c|c|c|c|}
\hline Study & Operating conditions & Main findings & Reference \\
\hline $\begin{array}{l}\text { Effects of moisture } \\
\text { content, torrefaction } \\
\text { temperature, and die } \\
\text { temperature in pilot } \\
\text { scale pelletizing of } \\
\text { torrefied Norway spruce }\end{array}$ & $\begin{array}{l}\text { - } \text { moisture content: } 11 \%-15 \% \\
\text { - } \quad 270^{\circ} \mathrm{C}-300^{\circ} \mathrm{C} \\
\text { - die temperature }: 60^{\circ} \mathrm{C}-105^{\circ} \mathrm{C} \\
\text { - } \text { bulk densities: } 630-710 \mathrm{~kg} / \mathrm{m}^{3}\end{array}$ & $\begin{array}{l}\text { at too high moisture contents, other problems such } \\
\text { as low bulk density and feeding problems } \\
\text { predominate } \\
\text { pellet moisture contents were decided by } \\
\text { torrefaction temperatures, and not by ingoing } \\
\text { material moisture contents } \\
\text { - } \begin{array}{l}\text { working at high die temperatures is a } \\
\text { promising alternative }\end{array}\end{array}$ & [63] \\
\hline $\begin{array}{l}\text { Implications of fuel } \\
\text { moisture content and } \\
\text { distribution on the fuel } \\
\text { purchasing strategy } \\
\text { of biomass cogeneration } \\
\text { power plants }\end{array}$ & $\begin{array}{l}\text { - } \quad \text { assuming the fuel cost followed by } \\
\text { detailed engineering design, project cost } \\
\text { estimation and economic analysis } \\
\text { - developing mathematical models of fuel } \\
\text { cost incorporating various fuel parameters } \\
\text { and power plant operating parameters }\end{array}$ & $\begin{array}{l}\text { the maximum affordable fuel cost depend on } \\
\text { the fuel moisture content, area-base annual } \\
\text { availability, the required financial return, size of } \\
\text { the power plant, and the operation of the power } \\
\text { plant }\end{array}$ & [68] \\
\hline $\begin{array}{l}\text { Effect of initial moisture } \\
\text { content on the yields of } \\
\text { oily products from } \\
\text { pyrolysis of biomass }\end{array}$ & $\begin{array}{l}\text { - } \quad \text { size range : } 0.180-0.250 \mathrm{~mm} \\
\text { - } \quad \text { dried samples ( } 0 \% \text { moisture), air } \\
\text { - } \quad \text { dried samples, wet samples and in } \\
\text { nitrogen medium }\end{array}$ & $\begin{array}{l}\text { - yields of total oily products increased with } \\
\text { increasing pyrolysis temperature } \\
\text { - } \quad \text { presence of moisture influenced significantly } \\
\text { the thermal degradation degrees of the biomass } \\
\text { samples during pyrolysis due to quenching }\end{array}$ & {$[70]$} \\
\hline $\begin{array}{l}\text { Effects of compressive } \\
\text { force, particle size and } \\
\text { moisture content on } \\
\text { mechanical properties of } \\
\text { biomass pellets from } \\
\text { grasses }\end{array}$ & $\begin{array}{l}\text { biomass samples compressed with five } \\
\text { levels of compressive forces }(1000,2000 \text {, } \\
3000,4000 \text { and } 4400 \mathrm{~N}) \text { and three levels } \\
\text { of particle sizes (3.2, } 1.6 \text { and } 0.8 \mathrm{~mm}) \text { at } \\
\text { two levels of moisture contents }(12 \% \\
\text { and } 15 \%) \text { (wet basis) }\end{array}$ & $\begin{array}{l}\text { compressive force, particle size and moisture } \\
\text { content significantly affected the pellet density } \\
\text { of barley straw, corn stover and switchgrass. } \\
\text { As moisture content of biomass increased, } \\
\text { pellet density decreased. }\end{array}$ & [71] \\
\hline
\end{tabular}

\subsection{Traditional Kilns and Retorts}

Producing charcoal using traditional kilns liberates greenhouse gases, particularly methane and nitrous oxide, conserves relatively small proportions of carbon in the feedstock [79] and wastes the heat energy created during production. Controlled pyrolysis stabilizes some carbon in solid form and also captures energy-rich liquids and gases which can be used to drive the pyrolysis reactions or used elsewhere [7]. Retort methods are effective at excluding oxygen to facilitate pyrolysis but can be costly during scale-up because of the need to control the atmosphere with sealed systems in conjunction with the use of inert gas [18]. Retort technology is the standard method of production for industrial charcoal in western countries, but due to high investment costs, it is not viable for traditional charcoal makers in the so called south countries [80]. Pyrolysis could be more efficient in terms of carbon emissions $\left(\mathrm{CO}_{2} \mathrm{MJ}^{-1}\right)$ and production of biochar carry greater abatement potential than biomass combustion, provided there is an overall adequate supply of feedstock and storage for the biochar product. Producing biochar using kilns is a simple technology and easy to adopt. The limitation attached to this method is the significant feedstock burn off, lower char yields and no heat recovery within the kiln system. The advantages derived from a given technology are rooted in its mode of operation and design concept. In general, the thermochemical conversion of organic biomass is influenced strongly by the production technologies. This was shown by the fundamentally different resulting chemical properties of biochars and hydrochars produced with gasification, pyrolysis and hydrothermal carbonization [20]. During their study these authors found that hydrochars have a less stable structure (dominated by alkyl moieties) than biochars (dominated by aromatics). Biochar should thus be produced under promising technologies not to compromise their stability in the soil. Table 9 compares the various reactors and the numerous advantages and disadvantages arising from them.

\subsection{Choice for Selection and Design of a Gasification System}

The ease to adopt a technology for biochar production is based on a number of major engineering as well as socio-economic factors [81] such as: 
Table 8. A summary of relevant literature investigating effect of ER on biomass gasification.

\begin{tabular}{|c|c|c|c|c|}
\hline Study type & Type of gasifier & Operating conditions & Particle size & Main findings \\
\hline $\begin{array}{l}\text { Experimental } \\
\text { investigation and } \\
\text { modelling study of } \\
\text { long stick wood } \\
\text { gasification in a } \\
\text { top lit updraft } \\
\text { fixed bed gasifier }\end{array}$ & TLUG & $\begin{array}{l}\text { MC: } 25 \%, 180 \mathrm{~W} \\
\text { of blower power } \\
\text { air supply, } \\
\text { T: } 432^{\circ} \mathrm{C}-936^{\circ} \mathrm{C} \\
\text { ER: } 0.26-0.43 \\
\text { H: nd } \\
\text { D: nd }\end{array}$ & $\begin{array}{l}\text { sticks with } \\
\text { length } \sim 68 \\
\text { cm and } \\
\text { diameter } \\
\sim 6 \mathrm{~cm}\end{array}$ & $\begin{array}{l}\text { - measurement of the ER is a simple way of } \\
\text { analyzing the behavior of the gasifier } \\
\text { - TLUG gasified } 90 \mathrm{~kg} \text { of wood for } 10 \mathrm{~h} \text { in t } \\
\text { batches per day }\end{array}$ \\
\hline $\begin{array}{l}\text { Low temperature } \\
\text { gasification of olive } \\
\text { kernels in a 5-kW } \\
\text { fluidized bed } \\
\text { reactor for } \mathrm{H}_{2} \text {-rich } \\
\text { producer gas }\end{array}$ & $\begin{array}{l}\text { 5-kW } \\
\text { fluidized } \\
\text { bed reactor }\end{array}$ & $\begin{array}{l}\text { MC: } 10 \% w t-12 \% \text { wt } \\
\text { T: } 750^{\circ} \mathrm{C}-850^{\circ} \mathrm{C} \text { and } \\
\text { ER: } 0.2-0.4 \\
\text { H: } 1400 \mathrm{~mm}\end{array}$ & $\begin{array}{l}\text { Bulk density } \\
\left(\mathrm{kg} / \mathrm{m}^{3}\right): 573 \\
\text { size fraction } \\
\text { of olivine } \\
(500-425 \mu \mathrm{m})\end{array}$ & $\begin{array}{l}\text { increase in ER deteriorated producer gas } \\
\text { quality, decreased } \mathrm{H}_{2} \text { content and favored } \\
\mathrm{CO}_{2} \text {, thus lowering producer gas heating } \\
\text { value }\end{array}$ \\
\hline
\end{tabular}

Reference

T: $700^{\circ} \mathrm{C}-900^{\circ} \mathrm{C}$

a fluidized bed reactor of atmospheric pressure

Biomass feed rate: $0.445 \mathrm{~kg} / \mathrm{h}$;
An experimental study on biomass air-steam fluidized bed

Experimental investigation of a downdraft biomass gasifier gasification in a in $50^{\circ} \mathrm{C}$ increments air: $0.5 \mathrm{~m}^{3} / \mathrm{h}$; steam rate: $1.2 \mathrm{~kg} / \mathrm{h}$ ER: 0.22; S/B: 2.7

$\begin{array}{ll}\text { a blow-type } & \text { H: } 2.5 \mathrm{~m} \\ \text { downdraft } & \text { ID: } 600 \mathrm{~mm} \\ \text { gasifier } & \text { ER: } 0.268-0.43\end{array}$

$\mathrm{H}_{1}: 1050 \mathrm{~mm}$ and $\mathrm{H}_{2}: 1800 \mathrm{~mm}$ downdraft moving bed gasifiers (25 $300 \mathrm{~kg} / \mathrm{h}$ )-design, experimental aspects and results

Effect of pyrolysis temperature and heating rate on biochar obtained from pyrolysis of safflower seed press cake

Simplifying pyrolysis: Using gasification to produce corn stover and wheat straw biochar for sorptive and horticultural media downdraft moving bed gasifiers

- Feed: 5 - $6 \mathrm{~kg}$ unchanging air flow: $100 \mathrm{~N} \cdot \mathrm{m}^{3} / \mathrm{hr}$, FCR: $50 \mathrm{~kg} / \mathrm{h}$ and SGR: $0.283 \mathrm{~kg} / \mathrm{s} \cdot \mathrm{m}^{2}$

Particle size: $84 \%$ between 0.5 and $16 \mathrm{~mm} \bullet$

H: $104 \mathrm{~mm}$

ID: $70 \mathrm{~mm}$

feed: $20 \mathrm{~g}$

fixed-bed reactor

- inert gas (nitrogen) ${ }^{\text {average }}$

- $\mathrm{T}=400^{\circ} \mathrm{C}, 450^{\circ} \mathrm{C}, 1.8 \mathrm{~mm}$ particle $500^{\circ} \mathrm{C}, 550^{\circ} \mathrm{C}$ and $600^{\circ} \mathrm{C}$

$30^{\circ} \mathrm{C}$ and $50^{\circ} \mathrm{C} \cdot \mathrm{min}^{-1}$

- average temperatures

CS: $520 \pm 150$

top-lit

updraft

cookstove

$6 \mathrm{~mm}$ diamete

by 8 - $10 \mathrm{~mm}$ heating rates: $10^{\circ} \mathrm{C}$,
WS: $550 \pm 25$

WS + GT: $595 \pm 80$

- gasification time: $30 \mathrm{~min}$

$\mathrm{H}$ : nd

ID: nd

ER: nd size: $0.3-0.45$
mm, silica sand (particle size $0.2-0.3$ $\mathrm{mm}$ ) as bed material

size of the biomass material (wood chips and furniture wood + charcoal) used was equivalent to $50 \mathrm{~mm}$ cube

- the LHV of fuel gas decreased with ER the introduction of steam improved gas quality compared to biomass air gasification but excessive steam would lower gasification temperature and so degrade fuel gas quality

- smaller particle more favorable for higher gas LHV and yield

- calorific value of the producer gas increases with ER initially, attains a peak and then decreases with the increase in ER

- the gas flow rate per unit weight of the fuel increases linearly with ER

complete conversion of carbon to gaseous fuel did not occur even for the optimum ER optimum ER (0.38) for the best performance of the downdraft biomass gasifier

- air flow is an influential variable and it determines the biomass consumption and the gas and solid production

mass conversion efficiency (MCE) and cold gas efficiency (CGE) values increase with ER

- biochar yield and quality depend principally on the applied temperature where pyrolysis at $600^{\circ} \mathrm{C}$ leaves a biochar with higher fixed carbon (80.7\%) and relative carbon content (73.8\%), and higher heating value (30.3 $\mathrm{MJ} \cdot \mathrm{kg}^{-1}$ ) in comparison with the original feedstock (SPC) and low VM content $(9.80 \%)$

- the biochars had low surface areas (1.89 - 4.23 $\mathrm{m}^{2} / \mathrm{g}$ ) and contained predominantly aromatic compounds

- biochar from the gasification process had carbon content $>70 \%$ and an ash content of $25 \%$ which was equal or better than the same biochar produced using the retort oven

pellets size: - the same biochar showed successful use as a peat moss replacement in horticultural applications

long

- gasification is a simpler, more cost-effective means to produce biochars and should be considered for horticultural and other similar applications
[23]

nd: no details; H: height; ID: internal diameter; CS: corn stover; WS: wheat straw; MC: moisture content. 
Table 9. Comparison of various types of reactors for biochar production [16].

\begin{tabular}{|c|c|c|c|c|}
\hline $\begin{array}{l}\text { Process } \\
\text { type }\end{array}$ & Reactor type & $\begin{array}{l}\text { Examples of equipment } \\
\text { manufacturers }\end{array}$ & Advantages & Disadvantages \\
\hline Batch & $\begin{array}{l}\text { Earth pits and } \\
\text { mounds } \\
\text { Brick, concrete and } \\
\text { double metal kilns } \\
\text { Retorts }\end{array}$ & & $\begin{array}{l}\text { Simple technology, } \\
\text { cheap and portable }\end{array}$ & $\begin{array}{l}\text { Inefficient leading to low yield; no } \\
\text { heat recovery, significant feedstock } \\
\text { burn off; release of pyrolysis gas } \\
\text { and vapors to atmosphere resulting } \\
\text { in environmental pollution }\end{array}$ \\
\hline \multirow{4}{*}{ Continuou } & Retort & Lambiotte retort & $\begin{array}{l}\text { The operating time for the retort-kiln } \\
\text { is much shorter, about } 12 \mathrm{~h} \\
\text { (plus about } 12 \mathrm{~h} \text { for cooling) }\end{array}$ & $\begin{array}{l}\text { High investment costs and not viable } \\
\text { for traditional charcoal makers in } \\
\text { the so called south countries }\end{array}$ \\
\hline & \multicolumn{4}{|c|}{ Multiple hearth reactors } \\
\hline & $\begin{array}{l}\text { Screw type } \\
\text { pyrolysers }\end{array}$ & $\begin{array}{l}\text { Pyro-7 by } \\
\text { Pro-Natura; } \\
\text { Biofuel } \\
\text { Energy Systems Ltd. }\end{array}$ & $\begin{array}{l}\text { Higher yields; feedstock flexibility; } \\
\text { heat integration; possible cogeneration } \\
\text { of char and energy; easy to operate, } \\
\text { relatively proven technology; combined } \\
\text { char and energy generation; available } \\
\text { as either portable or stationary unit } \\
\text { (depending on size) }\end{array}$ & $\begin{array}{l}\text { More complex systems; more } \\
\text { expensive than batch processes; } \\
\text { No usable by-products }\end{array}$ \\
\hline & $\begin{array}{l}\text { Paddle drum type } \\
\text { reactors }\end{array}$ & $\begin{array}{l}\text { BEST Energies, } \\
\text { Australia }\end{array}$ & $\begin{array}{l}\text { Relatively proven technology; feedstock } \\
\text { flexibility; combined char and energy } \\
\text { generation; available as either portable } \\
\text { or stationary unit (depending on size); } \\
\text { higher yields, heat integration and } \\
\text { possible cogeneration of char and energy }\end{array}$ & $\begin{array}{l}\text { More complex systems; } \\
\text { more expensive than } \\
\text { batch processes }\end{array}$ \\
\hline
\end{tabular}

- Effectiveness: The reactor should use chemical and thermal energy efficiently to produce a maximum amount of biochar in an environmentally friendly manner.

- Fuel flexibility: Reactor should be able to pyrolyze a variety of biomass feedstocks.

- Operation: Reactor should be easy to start up and control during operation.

- Mobility: Reactor should be low-weight and of simple design to allow for ease of translocation between farmer fields.

- Prestige: The reactor should be attractive and able to give pride to the user.

- Time-saving: Reactors with long holding times or low throughput capacity are likely not of interest to farmers.

- Quality: The quality should be customized to meet the end user's ability to procure.

- Spare parts and maintenance: The ease to replace broken material is a very attractive engineering tool in designing the reactor.

- Health and safety: Reactor must be safe to operate. Pressure build-up should be avoided by installing pressure relief valves if required. Hot reactor surfaces should be avoided by good thermal insulation to minimize risk of skin burns. Release of toxic or irritant smoke must be minimized by ensuring complete combustion of pyrolysis gases.

- Familiarity: Users ease to adopt and familiarize with the reactor is an important ingredient in the design.

- Affordability: Whereas other parameters are pretty important, the price of the reactor has to be tailored to meet the users' ability. An expensive reactor may not be easily adopted and so is a very cheap one.

- Consumer-driven technologies: The reactor should be in position to solve a problem that attracts its design. This will add value to attracting the consumers to adopt it due to its ability to meet the end users goal.

The design of biomass gasifiers is thus an emerging concept aimed at providing solutions to a number of engineering problems. [82] designed, evaluated and optimized the performance of an energy efficient biomass gasifier-based cookstove using babul wood (Prosopis julliflora), goundnut (Arachis hypogaea) shell briquettes, sawdust briquettes and cashew nut (Anacardium occidentale) shells. A 35\% thermal efficiency with 1.53 to $1.76 \mathrm{~kW}$ of power rating and a maximum flame temperature of $763^{\circ} \mathrm{C}$ was recorded when cashew nut shells were used as feedstock. [83] designed, manufactured and evaluated the performance efficiency of the house hold gasifier 
stove. The gasifier reactor had an internal diameter of $24 \mathrm{~cm}$ and an overall dimension of $30.4 \mathrm{~cm}$ diameter by $70 \mathrm{~cm}$ height and a specific fuel consumption of $1.3 \mathrm{~kg} / \mathrm{hr}$. The performance efficiency of the stove was evaluated using water boiling test and a thermal efficiency of $17.2 \%$ was obtained. Their results showed that the gasifier performance and operating conditions were good and the stove could provide modern energy services for basic needs and productive applications in the rural areas. [84] developed an $11.2 \mathrm{~kW}$ laboratory scale updraft gasifier that was tested using sawdust and palm kernel shell (PKS) as feedstock. The gasifier performance for both sawdust and PKS comprised of chemical energy inputs of 28,125 and $31633.06 \mathrm{~kJ}$, power input of 7.81 and $8.79 \mathrm{~kW}$, power output of 5.47 and $6.15 \mathrm{~kW}$ and the respective gasifier efficiencies of $93 \%$ and $67.4 \%$ and would meet various applications of heating, electricity supply and could be used to generate the needed combustible gases during fuel scarcity. From the reported literature above, it is important to note that the performance of the gasifier is feedstock-specific. This is due to differences in particle density and the minimum amount of air allowed for gasification. Notwithstanding the efforts from previous researchers, the prospect for available gasifiers to process biochar remains missing. There is need to design and test gasifiers with available feedstocks putting emphasis on biochar production. This will provide an innovative means for producing biochar and making it more accessible to the users.

\section{System Energy Efficiency and Economics}

A system is a group of devices or objects whose interaction serves a common purpose. It is possible to have an energy efficient system during biochar production through effective thermal insulation to avoid heat losses, ensuring an effective ignition system during start up as well as proper direction and use of the generated heat during biochar production. The energy efficiency of a biochar manufacturing technology is a critical ingredient as a choice for a biochar system. As the energy efficiency decreases, emissions increase due to incomplete combustion products. It is thus important to consider a system whose energy efficiency is well maintained with lesser or no energy losses during the thermo-chemical processes. Although a certain amount of fossil fuel may be needed at some stages of the biochar making process such as for the ignition processes, systems that require more fossil fuel offer less greenhouse abatement benefits and are less energetically desirable [85]. Fossil energy savings and GHG mitigation will be increased if the technology is vertically integrated to use process residues internally to run the biomass conversion plant [86]. The technology that has the potential to provide both ecological and economic benefits of the system will make its application more sustainable. The technology producing more than one product through the coproduction of usable bioenergy in addition to biochar, instead of simply flaring the gases and oils produced from the process is more promising because the raw material is split between more products. Technologies with broad feedstock specifications with respect to particle size distribution, chemical composition (ash content), and moisture content will be the most flexible [85] and marketable. By executing measuring, monitoring and verifying (MMV) protocols for all energy inputs required by the technology accounts for GHG reduction purposes. It is thus important for all biochar related works to advocate for energy efficient technologies as well as biochar projects should source technologies that employ energy efficiency practices to mitigate the environmental risks associated with a particular process.

\subsection{Use of a Hood for Emission Monitoring in Stoves}

The use of a hood has been extensively used for a number of studies in emission factor measurements [87]-[92]. The basic concept of the hood is to construct it above the tested device to capture all the emissions, making the unvented stove as if a ducted emission source [90]. [88] revealed that the presence of an extraction hood could change combustion characteristics of the stove because it could change the fuel combustion characteristics independent of the stove type and the stove air inlet could be influenced by the forced extraction. To avoid large measurement errors, this method requires a constant and steady exhaust flow rate during the entire burning test as well as the isokinetic sampling for larger particles [90]. By directly measuring the air flow in the hood, problems that make emission monitoring difficult can be avoided [92]. By performing a study to investigate and quantify fire power, fire temperatures, thermal efficiencies, and emissions, the influence of reasonable hood extraction levels on the performance of a number of cooking device, the potential for the forced extraction of flue gases to change the combustion characteristics of unvented biomass-burning cooking devices was assessed [88]. The performance of three stoves with different air inlet characteristics was measured using three hood extraction rates. These extraction rates were selected between the boundaries of being sufficiently low to have no visual 
impact on a flame at the height of the stove and being high enough to capture all emissions. Fire power, fire temperature and thermal efficiency were found not to be affected by the hood extraction rates. Sulphur dioxide and total suspended particles showed no significant effect of extraction at a 95\% confidence level while a measurable influence of extraction on carbon monoxide emissions was detected, but this was considerably smaller than the effect of the stove. There was no detectable interaction between stove type and extraction level indicating that the influence of the extraction on emissions is independent of the type of stove. The authors concluded that, provided the extraction level does not change between tests and falls between their tested boundaries, it is possible to use an extraction hood to compare emissions from different stoves. Table 10 summarizes pollutant emission factor monitoring studies from biomass gasification. From these studies it can be inferred that biomass must be gasified under optimized conditions to minimize these emission factors. It is feasible that comparisons between emissions from different cooking devices may be made without the aid of air-flow measurements thereby significantly simplifying and reducing the cost of emission assessment in the stove design. For the hood design methodology, [93] proposed a hood which was described in details by [94]. The tower is in the form of an inverted funnel with a cylindrical bottom, $1.0 \mathrm{~m}$ in diameter and $1.9 \mathrm{~m}$ high. From the top of the cylinder, the tower decreases to $0.2 \mathrm{~m}$ in a length of $1.0 \mathrm{~m}$ and is topped with a stack $1.2 \mathrm{~m}$ in height. This design has the potential to vent out the flue gases at turbulent flows because of the decreasing diameter of the inlet and outlet. Sampling of gases at turbulent flow ensures a representative sampling of the emissions coming out from the stove.

Table 10. Emission factor monitoring studies from biomass gasification.

\begin{tabular}{lll}
\hline \multicolumn{1}{c}{ Study type } & Major parameters & \multicolumn{1}{c}{ Main findings } \\
\hline $\begin{array}{l}\text { Thermal performance and } \\
\text { emission characteristics of } \\
\begin{array}{l}\text { unvented biomass-burning } \\
\text { cook stoves: A proposed } \\
\text { standard method for evaluation }\end{array}\end{array} \quad \begin{array}{l}\text { measure emissions } \\
\text { of air pollutants }\end{array}$ & $\begin{array}{l}\text { Acacia nilotica ranged between } 13 \mathrm{and} 68 \mathrm{~g} \cdot \mathrm{kg}^{-1} \mathrm{for} \mathrm{CO} \\
\text { and between } 1.1 \text { and } 3.9 \mathrm{~g} \cdot \mathrm{kg}^{-1} \mathrm{for} \text { total suspended } \\
\text { particulates and to increase with increasing thermal } \\
\text { efficiency both within and across stoves }\end{array}$ \\
\hline
\end{tabular}

Reference

Major gaseous and $\mathrm{PAH}$ emissions from a fluidized-bed combustor firing rice husk with high combustion efficiency

Emissions from multiple-spouted and spout-fluid fluidized beds using rice husks as fuel

Combustion and emission characteristics of a swirling fluidized-bed combustor (SFBC) burning moisturized rice husk

GHG emission mitigation potential of rice husks for An Giang province, Vietnam
- investigate $\mathrm{CO}, \mathrm{NO}_{\mathrm{x}}$ and $\bullet$ PAH emissions from a $400 \mathrm{~kW}_{\text {th }}$ fluidized-bed combustor with a cone-shaped bed, over $99 \%$, combustion efficiency

- investigate emissions of $\mathrm{CO}$ and $\mathrm{CO}_{2}$ on different configurations of spout-fluidized beds

- vary level of excess air, different primary-tosecondary air ratios at each level of excess air and method of feeding

- the swirling fluidized-bed combustor was tested at a constant fuel feed rate (of about $80 \mathrm{~kg} / \mathrm{h}$ ) for six fuel-moisture contents (from $8.4 \%$ to $35 \%$ )

- to evaluate the GHG emission mitigation potential of rice husk utilization through life cycle inventory analysis excess air had substantial effects on the axial CO and $\mathrm{NO}_{\mathrm{x}}$ concentration profiles

- the total PAHs emission was predominant for the coarsest ash particles

- the highest emission was shown by acenaphthylene, $4.1 \mu \mathrm{g} / \mathrm{kWh}$, when the total yield of PAHs via fly ash was about $10 \mu \mathrm{g} / \mathrm{kWh}$.

emission of CO seemed to be lower with under-bed feeding of the rice husk fuel compared to over-bed feeding

- $\mathrm{CO}_{2}$ emissions independent of method of feeding

- changes in excess air levels influenced the emissions of $\mathrm{CO}$ and $\mathrm{CO}_{2}$ within the excess air range investigated

- emission of CO was less at $10 \%$ excess air with over-bed feeding; emission of $\mathrm{CO}$ in the case of under-bed feeding was lowest at $20 \%$ excess air level

- emission of CO was less in the spout-fluid bed than $\mathrm{CO}$ in the multiple-spouted bed.

with increasing fuel-moisture content, the emission of NO from the combustor apparently reduced, while the emission of $\mathrm{CO}$ was adjusted at a quite low level due to the effects of secondary air

effective least-cost control of both $\mathrm{NO}$ and $\mathrm{CO}$ emissions with over $99 \%$ combustion efficiency are achievable when firing moisturized rice husk

- $\mathrm{CH}_{4}$ and $\mathrm{N}_{2} \mathrm{O}$ emissions from open burning contribute largely to the current GHG emissions

- briquettes can contribute to GHG emission mitigation as the production is more efficient than rice husk burning or dumping

- Gasification the most efficient GHG mitigator 


\subsection{Economics of Biochar Production}

A number of studies are geared to verifying the economic value of biochar in crop production and carbon sequestration [40] [99]-[103] (Table 11). The investigations by [99] [101] [103] suggest that the economic viability of the pyrolysis-biochar system is largely dependent on the costs of feedstock production, pyrolysis, and the

Table 11. Economic studies related with biochar production.

\begin{tabular}{|c|c|c|}
\hline Study type & Economic variables & Main findings \\
\hline $\begin{array}{l}\text { Biomass availability, } \\
\text { energy consumption } \\
\text { and biochar } \\
\text { production in rural } \\
\text { households of } \\
\text { Western Kenya }\end{array}$ & $\begin{array}{l}\text { on farm assessment of the } \\
\text { energy consumption for food } \\
\text { preparation, the biomass } \\
\text { availability relevant to } \\
\text { conventional and pyrolytic } \\
\text { cook stoves and the potential } \\
\text { biochar generation in rural } \\
\text { households of western Kenya }\end{array}$ & $\begin{array}{l}\text { biomass availability for pyrolysis varied widely from } 0.7 \text { to } 12.4 \\
\mathrm{Mg} \cdot \mathrm{ha}^{-1} \mathrm{y}^{-1} \text { with an average of } 4.3 \mathrm{Mg} \cdot \mathrm{ha}^{-1} \mathrm{y}^{-1} \text {, across all } 50 \\
\text { studied farms } \\
\text { the introduction of a first-generation pyrolytic cook stove reduced } \\
\text { wood energy consumption by } 27 \% \text { while producing an average } \\
\text { of } 0.46 \mathrm{Mg} \cdot \mathrm{ha}^{-1} \mathrm{y}^{-1} \text { of biochar }\end{array}$ \\
\hline
\end{tabular}

Economics of charcoal $\bullet$ assigning monetary values production in miombo woodlands of eastern Tanzania: some hidden costs associated with commercialization of the resources to commercial production of charcoal (using traditional earth kilns) in the miombo woodlands surrounding Kitulanghalo Forest Reserve in eastern Tanzania, through cost-benefit analysis (CBA)
- the profit from charcoal production is attributable to very low capital outlays, "free" own labor, "free" raw materials, lack of concern about associated external costs and high demand for charcoal

- when the cost of labor, raw materials and opportunity costs were considered, the NPV value was negative (US \$-868 ha-1), indicating that profit realization is accomplished at the expense of other potential uses of the woodlands

- although commercialization of wood resources provides tangible monetary benefits, it contributes to the resource depletion that threaten their long-term survival

- $\quad$ FBFP was economically better than FBFPCT for the production of primary pyrolysis oil that could be used as boiler fuel oil and for the production of catalytically treated upgraded, liquid-products rice husk pyrolysis, conversion with catalytic treatment to produce liquid fuel

Technical, economical, and climate-related aspects of biochar production technologies: A literature review
Fluidized Bed Fast Pyrolysis (FBFP) and Fluidised Bed Fast Pyrolysis with Catalytic Treatment (FBFPCT)
- The FBFP $1000 \mathrm{~kg} / \mathrm{h}$ plant unit appeared to be economically feasible, with the lowest unit production cost of primary pyrolysis oil

- $\quad$ a wide range of data on the costs of char production (between 51 US \$ per ton pyrolysis biochar from yard waste and 386 US \$ per ton retort charcoal) and on the GHG balance of biochar systems (between $1054 \mathrm{~kg} \mathrm{CO} 2 \mathrm{e}$ and $+123 \mathrm{~kg} \mathrm{CO}_{2} \mathrm{e}$ per t dry biomass feedstock) were published

- carbonization technologies (pyrolysis, gasification, hydro-thermal carbonization, and flash carbonization)

- more data from pilot projects are needed to improve the evaluation of biochar production technologies

additional research on the influence of biochar application on surface albedo, atmospheric soot concentration, and yield responses is necessary to assess the entire climate impact of biochar systems

- further field trials on the ability of different technologies to produce chars for agricultural soils and carbon sequestration are essential for future technology evaluation

- the economic viability of the pyrolysis-biochar system is largely dependent on the costs of feedstock production, pyrolysis, and the value of $\mathrm{C}$ offsets

Life cycle assessment

- using life cycle assessment to estimate the energy and of biochar systems: Estimating the energetic, economic and climate change climate change impacts and the economics of biochar systems potential.

- $\quad$ agricultural residues (corn stover), yard waste, and switch grass energy crops were used
- biomass sources that have a need for waste management such as yard waste have the highest potential for economic profitability $\left(+\$ 69 \mathrm{t}^{-1}\right.$ dry feedstock when $\mathrm{CO}_{2} \mathrm{e}$ emission reductions are valued at $\$ 80 \mathrm{t}^{-1} \mathrm{CO}_{2} \mathrm{e}$ )

- the transportation distance for feedstock creates a significant hurdle to the economic profitability of biochar-pyrolysis systems

- biochar may at present only deliver climate change mitigation benefits and be financially viable as a distributed system using waste biomass 
value of $\mathrm{C}$ offsets. It may be profitable to apply biochar as a soil amendment under some conditions if the biochar market price is low enough and/or a carbon offset market exists. [104] further proposed that the price of biochar has a bearing in accordance with its production temperature. Profitability was sensitive to the biochar selling price with a break-even at a biochar price of about $\$ 220 / \mathrm{t}$ for the pyrolysis at $300^{\circ} \mathrm{C}$ and about $\$ 280 / \mathrm{t}$ for pyrolysis at $450^{\circ} \mathrm{C}$. Economic biochar renders financial benefits to the user which includes increased production and reduced fertilizer requirements. In addition, the biochar producer or user may benefit from carbon credit under an emissions trading scheme. The producer could receive credits for stabilizing organic carbon, avoiding emissions from decomposition; alternatively, the landholder may receive credits for increasing the soil carbon stock in his field where biochar is applied. With the growing cost of waste disposal and implementation of renewable energy targets, the production and application of biochar and waste management will become more economically viable. Numerous studies have focused on the properties and application rates of biochar and their impacts on agricultural productivity [1] [2] [15] [16], while others examined biochar's potential in sequestering carbon [8] [33] [40] [101] yet there is a gap to link biochar production from portable midscale reactors if conventional farmers are to produce their own biochar. The economic feasibility for using a biochar production system is important for product commercialization. Factors such as operational costs, fixed costs and revenues from biochar production and sales must be considered [105].

\section{Biochar Production and Forest Security}

Although the application of biochar to soil has great environmental and agricultural contributions, controversy related to its application does exist, especially if timber is cut from forests specifically for use as a biochar feedstock material. If timber is primarily cut for biochar production, this could lead to deforestation and subsequently threaten food security since this could compromise on the amount of rainfall useful for agriculture. However, this can be avoided if biochar is produced from waste material such as waste wood, saw dust, rice husk, rice straw, empty fruit bunches, etc. instead of merely burning them. Slash and char can keep up to $50 \%$ of the carbon in a highly stable form [1]. Thus biochar production from agricultural wastes must be encouraged to avoid the extinction of forests.

\section{Conclusion}

Based on the reviewed work, there is need to develop and promote efficient technologies that can be integrated into biochar production systems. Such technologies should be easily adaptable to enable sustainable, low emission biochar production for both the users and the environment. There is need to develop mobile but economical technologies at midscale levels that can be adopted by small scale farmers. Economic technologies striking a balance between good technical performances and mobility could easily be adopted into the local community for sustainable biochar production. Most studies have focused on the properties and application rates of biochar and their impacts on agricultural productivity while others examine biochar's potential in sequestering carbon. There is lack of understanding on how a particular biochar technology impacts biochar production costs as well as biochar properties. It is thus important to investigate on how change in ER affects rice husk char properties for autothermal gasification systems. Linking rice husk biochar production with the costs involved makes the research path more certain with prospects for investments. Thus, the need to develop and test portable but economically viable rice husk gasification technologies remains relevant.

\section{References}

[1] Lehmann, J., Gaunt, J. and Rondon, M. (2006) Bio-Char Sequestration in Terrestrial Ecosystems-A Review. Mitigation and Adaptation Strategies for Global Change, 11, 395-419. http://dx.doi.org/10.1007/s11027-005-9006-5

[2] Verheijen, F., Jeffery, S., Bastos, A.C., Velde, M.V.D. and Diafas, I. (2009) Biochar Application to Soils-A Critical Scientific Review of Effects on Soil Properties, Processes and Functions. EUR 24099 EN Office for the Official Publications of the European Communities, Luxemburg, 149.

[3] Feng, Y., Xu, Y., Yu, Y., Xie, Z. and Lin, X. (2012) Mechanisms of Biochar Decreasing Methane Emission from Chinese Paddy Soils. Soil Biology and Biochemistry, 46, 80-88. http://dx.doi.org/10.1016/j.soilbio.2011.11.016

[4] Rajkovich, S., Enders, A., Hanley, K., Hyland, C., Zimmerman, A.R. and Lehmann, J. (2011) Corn Growth and Nitrogen Nutrition after Additions of Biochars with Varying Properties to a Temperate Soil. Biology and Fertility of Soils, 48, 271-284. http://dx.doi.org/10.1007/s00374-011-0624-7 
[5] Amonette, J. and Joseph, S. (2009) Characteristics of Biochar: Micro-Chemical Properties. In: Lehmann, J. and Joseph, S., Eds., Biochar for Environmental Management: Science and Technology, Earthscan, London, 33-52.

[6] Whitman, T. and Lehmann, J. (2009) Biochar-One Way Forward for Soil Carbon in Offset Mechanisms in Africa? Environmental Science \& Policy, 12, 1024-1027. http://dx.doi.org/10.1016/j.envsci.2009.07.013

[7] Sohi, S., Krull, E., Lopez-Capel, E. and Bol, R. (2010) A Review of Biochar and Its Use and Function in Soil. Advances in Agronomy, 105, 47-82. http://dx.doi.org/10.1016/S0065-2113(10)05002-9

[8] Bird, M.I., Wurster, C.M., De Paula Silva, P.H., Bass, A.M. and De Nys, R. (2011) Algal Biochar-Production and Properties. Bioresource Technology, 102, 1886-1891. http://dx.doi.org/10.1016/j.biortech.2010.07.106

[9] Laird, D.A., Brown, R.C., Amonette, J.E. and Lehmann, J. (2009) Review of the Pyrolysis Platform for Coproducing Bio-Oil and Biochar. Biofuels, Bioproducts and Biorefining, 3, 547-562. http://dx.doi.org/10.1002/bbb.169

[10] Kameyama, K., Miyamoto, T. and Shinogi, Y. (2010) Increases in Available Water Content of Soils by Applying Bagasse-Charcoals. 19th World Congress of Soil Science, Soil Solutions for a Changing World, 105-108. http://www.ldd.go.th/swcst/Report/soil/.\%5Csymposium/pdf/1663.pdf

[11] Apaydın-Varol, E. and Pütün, A.E. (2012) Preparation and Characterization of Pyrolytic Chars from Different Biomass Samples. Journal of Analytical and Applied Pyrolysis, 98, 29-36. http://dx.doi.org/10.1016/j.jaap.2012.07.001

[12] Cowie, A.L., Penman, T.D., Gorissen, L., Winslow, M.D., Lehmann, J., Tyrrell, T.D., Kellner, K., et al. (2011) Towards Sustainable Land Management in the Drylands: Scientific Connections in Monitoring and Assessing Dryland Degradation, Climate Change and Biodiversity. Land Degradation \& Development, 22, 248-260.

[13] Pratt, K. and Moran, D. (2010) Evaluating the Cost-Effectiveness of Global Biochar Mitigation Potential. Biomass and Bioenergy, 34, 1149-1158. http://dx.doi.org/10.1016/j.biombioe.2010.03.004

[14] Williams, M.M. and Arnott, J.C. (2010) A Comparison of Variable Economic Costs Associated with Two Proposed Biochar Application Methods. Williams and Arnott, Annals of Environmental Science, 4, 23-30. http://iris.lib.neu.edu/cgi/viewcontent.cgi?article=1056\&context=aes

[15] Lehmann, J. (2007) Bio-Energy in the Black. Frontiers in Ecology and the Environment, 5, 381-387. http://dx.doi.org/10.1890/1540-9295(2007)5[381:BITB]2.0.CO;2

[16] Duku, M.H., Gu, S. and Hagan, E.B. (2011) Biochar Production Potential in Ghana-A Review. Renewable and Sustainable Energy Reviews, 15, 3539-3551. http://dx.doi.org/10.1016/j.rser.2011.05.010

[17] Yao, Y., Gao, B., Inyang, M., Zimmerman, A.R., Cao, X., Pullammanappallil, P. and Yang, L. (2011) Biochar Derived from Anaerobically Digested Sugar Beet Tailings: Characterization and Phosphate Removal Potential. Bioresource Technology, 102, 6273-6278. http://dx.doi.org/10.1016/j.biortech.2011.03.006

[18] Peterson, S.C. and Jackson, M. (2014) Simplifying Pyrolysis: Using Gasification to Produce Corn Stover and Wheat Straw Biochar for Sorptive and Horticultural Media. Industrial Crops and Products, 53, 228-235. http://dx.doi.org/10.1016/j.indcrop.2013.12.028

[19] Ghani, W.A.W.A.K., Mohd, A., Da Silva, G., Bachmann, R.T., Taufiq-Yap, Y.H., Rashid, U. and Al-Muhtaseb, A.H. (2013) Biochar Production from Waste Rubber-Wood-Sawdust and Its Potential Use in C Sequestration: Chemical and Physical Characterization. Industrial Crops and Products, 44, 18-24. http://dx.doi.org/10.1016/j.indcrop.2012.10.017

[20] Wiedner, K., Rumpel, C., Steiner, C., Pozzi, A., Maas, R. and Glaser, B. (2013) Chemical Evaluation of Chars Produced by Thermochemical Conversion (Gasification, Pyrolysis and Hydrothermal Carbonization) of Agro-Industrial Biomass on a Commercial Scale. Biomass and Bioenergy, 59, 264-278. http://dx.doi.org/10.1016/j.biombioe.2013.08.026

[21] Reed, T.B. and Das, A. (1988) Handbook of Biomass Downdraft Gasifier Engine System. SERI, Golden, CO. http://taylor.ifas.ufl.edu/documents/handbook_of_biomass_downdraft_gasifier_engine_systems.pdf

[22] Cheng, G., Li, Q., Qi, F., Xiao, B., Liu, S., Hu, Z. and He, P. (2012) Allothermal Gasification of Biomass Using Micron Size Biomass as External Heat Source. Bioresource Technology, 107, 471-475. http://dx.doi.org/10.1016/j.biortech.2011.12.074

[23] Saravanakumar, A., Haridasan, T.M., Reed, T.B. and Bai, R.K. (2007) Experimental Investigation and Modelling Study of Long Stick Wood Gasification in a Top Lit Updraft Fixed Bed Gasifier. Fuel, 86, 2846-2856. http://dx.doi.org/10.1016/j.fuel.2007.03.028

[24] Patil, K.N., Singh, R.N. and Saiyed, S.U. (2002) Case Study of SPRERI Natural Draft Gasifier Installation at a Ceramic Industry. Biomass and Bioenergy, 22, 497-504. http://dx.doi.org/10.1016/S0961-9534(02)00009-0

[25] Anderson, P. (2009) CO and PM Emissions from TLUD Cookstoves. 2009 ETHOS Conference, Kirkland, 23-25 January 2009, Biomass Energy Foundation. http://stoves.bioenergylists.org/andersontludcopm

[26] Cedric, B., Piskorz, J. and Berruti, F. (2008) Biomass Valorization for Fuel and Chemicals Production-A Review. International Journal of Chemical Reactor Engineering, 6, 1542-6580. 
[27] Simon, G., Bumpus, A. and Mann, P. (2010) Win-Win Scenarios at the Climate-Development Interface: Challenges and Opportunities for Cookstove Replacement Programs through Carbon Finance Social Science Research Network. Working Paper Series. Global Environmental Change, 22, 275-287.

[28] Garrett, S. and Hopke, P.K. and Behn, W.H. (2010) A Research Road Map: Improved Cook Stove Development and Deployment for Climate Change Mitigation and Women's and Children's Needs. http://www.pciaonline.org/files/CookStoveResearchRoadMap.pdf

[29] Qurni, U. and Bachmann, R.T. (2014) Photovoltaic-Battery System to Power Fan-Controlled Rice Husk Gasifier Cooking Stove. Australian Journal of Basic and Applied Sciences, 8, 746-751.

[30] Anderson, P.S., Reed, T.B. and Wever, P.W. (2007) Micro-Gasification: What It Is and Why It Works. Boiling Point, 53, 35-37. http://www.hedon.info/docs/BP53-Anderson-14.pdf

[31] Tinaut, F.V., Melgar, A., Pérez, J.F. and Horrillo, A. (2008) Effect of Biomass Particle Size and Air Superficial Velocity on the Gasification Process in a Downdraft Fixed Bed Gasifier. An Experimental and Modelling Study. Fuel Processing Technology, 89, 1076-1089. http://dx.doi.org/10.1016/j.fuproc.2008.04.010

[32] Hossain, M.K., Strezov, V., Chan, K.Y., Ziolkowski, A. and Nelson, P.F. (2011) Influence of Pyrolysis Temperature on Production and Nutrient Properties of Wastewater Sludge Biochar. Journal of Environmental Management, 92, $223-$ 228. http://dx.doi.org/10.1016/j.jenvman.2010.09.008

[33] Glaser, B., Lehmann, J. and Zech, W. (2002) Ameliorating Physical and Chemical Properties of Highly Weathered Soils in the Tropics with Charcoal—A Review. Biology and Fertility of Soils, 35, 219-230. http://dx.doi.org/10.1007/s00374-002-0466-4

[34] Fu, P., Yi, W., Bai, X., Li, Z., Hu, S. and Xiang, J. (2011) Effect of Temperature on Gas Composition and Char Structural Features of Pyrolyzed Agricultural Residues. Bioresource Technology, 102, 8211-8219. http://dx.doi.org/10.1016/j.biortech.2011.05.083

[35] Paethanom, A. and Yoshikawa, K. (2012) Influence of Pyrolysis Temperature on Rice Husk Char Characteristics and Its Tar Adsorption Capability. Energies, 5, 4941-4951. http://dx.doi.org/10.3390/en5124941

[36] Al-Wabel, M.I., Al-Omran, A., El-Naggar, A.H., Nadeem, M. and Usman, A.R. (2013) Pyrolysis Temperature Induced Changes in Characteristics and Chemical Composition of Biochar Produced from Conocarpus Wastes. Bioresource Technology, 131, 374-379. http://dx.doi.org/10.1016/j.biortech.2012.12.165

[37] Enders, A., Hanley, K., Whitman, T., Joseph, S. and Lehmann, J. (2012) Characterization of Biochars to Evaluate Recalcitrance and Agronomic Performance. Bioresource Technology, 114, 644-653. http://dx.doi.org/10.1016/j.biortech.2012.03.022

[38] Maschio, G., Koufopanos, C. and Lucchesi, A. (1992) Pyrolysis, a Promising Route for Biomass Utilization. Bioresource Technology, 42, 219-231. http://dx.doi.org/10.1016/0960-8524(92)90025-S

[39] Zhang, Y., Li, B., Li, H. and Liu, H. (2011) Thermodynamic Evaluation of Biomass Gasification with Air in Autothermal Gasifiers. Thermochimica Acta, 519, 65-71. http://dx.doi.org/10.1016/j.tca.2011.03.005

[40] Meyer, S., Glaser, B. and Quicker, P. (2011) Technical, Economical, and Climate-Related Aspects of Biochar Production Technologies: A Literature Review. Environmental Science \& Technology, 45, 9473-9483. http://dx.doi.org/10.1021/es201792c

[41] Hernández, J.J., Ballesteros, R. and Aranda, G. (2013) Characterization of Tars from Biomass Gasification: Effect of the Operating Conditions. Energy, 50, 333-342. http://dx.doi.org/10.1016/j.energy.2012.12.005

[42] Ryu, C., Yang, Y.B., Khor, A., Yates, N.E., Sharifi, V.N. and Swithenbank, J. (2006) Effect of Fuel Properties on Biomass Combustion: Part I. Experiments—Fuel Type, Equivalence Ratio and Particle Size. Fuel, 85, 1039-1046. http://dx.doi.org/10.1016/j.fuel.2005.09.019

[43] Kumar, A., Jones, D.D. and Hanna, M. (2009) Thermochemical Biomass Gasification: A Review of the Current Status of the Technology. Energies, 2, 556-581. http://dx.doi.org/10.3390/en20300556

[44] Rapagnà, S., Gallucci, K., Di Marcello, M., Matt, M., Nacken, M., Heidenreich, S. and Foscolo, P.U. (2010) Gas Cleaning, Gas Conditioning and Tar Abatement by Means of a Catalytic Filter Candle in a Biomass Fluidized-Bed Gasifier. Bioresource Technology, 101, 7123-7130. http://dx.doi.org/10.1016/j.biortech.2010.03.139

[45] Kiel, J.H.A. and van Paasen, S.V.B. (2004) Tar Formation in a Fluidized Bed Gasifier: Impact of Fuel Properties and Operating Conditions. Report ECN-C-04-013, 1-58. http://www.ecn.nl/docs/library/report/2004/c04013.pdf

[46] Yang, H., Yan, R., Chen, H., Zheng, C., Lee, D.H. and Liang, D.T. (2006) In-Depth Investigation of Biomass Pyrolysis Based on Three Major Components: Hemicellulose, Cellulose and Lignin. Energy \& Fuels, 20, 388-393. http://dx.doi.org/10.1021/ef0580117

[47] Wannapeera, J., Worasuwannarak, N. and Pipatmanomai, S. (2008) Product Yields and Characteristics of Rice Husk , Rice Straw and Corncob During Fast Pyrolysis in a Drop-Tube/Fixed-Bed Reactor. Songklanakarin Journal of Science 
\& Technology, 30, 393-404.

[48] Demirbas, A., Pehlivan, E. and Altun, T. (2006) Potential Evolution of Turkish Agricultural Residues as Bio-Gas, BioChar and Bio-Oil Sources. International Journal of Hydrogen Energy, 31, 613-620. http://dx.doi.org/10.1016/j.ijhydene.2005.06.003

[49] Fushimi, C., Araki, K., Yamaguchi, Y. and Tsutsumi, A. (2003) Effect of Heating Rate on Steam Gasification of Biomass. 2. Thermogravimetric-Mass Spectrometric (TG-MS) Analysis of Gas Evolution. Industrial \& Engineering Chemistry Research, 42, 3929-3936. http://dx.doi.org/10.1021/ie0300575

[50] Jin, W., Singh, K. and Zondlo, J. (2013) Pyrolysis Kinetics of Physical Components of Wood and Wood-Polymers Using Isoconversion Method. Agriculture, 3, 12-32. http://dx.doi.org/10.3390/agriculture3010012

[51] Lewis, A.D. and Fletcher, T.H. (2013) Prediction of Sawdust Pyrolysis Yields from a Flat-Flame Burner Using the CPD Model. Energy \& Fuels, 27, 942-953. http://dx.doi.org/10.1021/ef3018783

[52] Fahmi, R., Bridgwater, V., Donnison, I., Yates, N. and Jones, J.M. (2008) The Effect of Lignin and Inorganic Species in Biomass on Pyrolysis Oil Yields, Quality and Stability. Fuel, 87, 1230-1240. http://dx.doi.org/10.1016/j.fuel.2007.07.026

[53] Mašek, O., Brownsort, P., Cross, A. and Sohi, S. (2013) Influence of Production Conditions on the Yield and Environmental Stability of Biochar. Fuel, 103, 151-155. http://dx.doi.org/10.1016/j.fuel.2011.08.044

[54] Crombie, K., Mašek, O., Sohi, S.P., Brownsort, P. and Andrew, C. (2013) The Effect of Pyrolysis Conditions on Biochar Stability as Determined by Three Methods. GCB Bioenergy, 5, 122-131.

[55] Angin, D. (2013) Effect of Pyrolysis Temperature and Heating Rate on Biochar Obtained from Pyrolysis of Safflower Seed Press Cake. Bioresource Technology, 128, 593-597. http://dx.doi.org/10.1016/j.biortech.2012.10.150

[56] Maiti, S., Dey, S., Purakayastha, S. and Ghosh, B. (2006) Physical and Thermochemical Characterization of Rice Husk Char as a Potential Biomass Energy Source. Bioresource Technology, 97, 2065-2070. http://dx.doi.org/10.1016/j.biortech.2005.10.005

[57] Hu, S., Xiang, J., Sun, L., Xu, M., Qiu, J. and Fu, P. (2008) Characterization of Char from Rapid Pyrolysis of Rice Husk. Fuel Processing Technology, 89, 1096-1105. http://dx.doi.org/10.1016/j.fuproc.2008.05.001

[58] Manyà, J.J., Roca, F.X. and Perales, J.F. (2013) TGA Study Examining the Effect of Pressure and Peak Temperature on Biochar Yield during Pyrolysis of Two-Phase Olive Mill Waste. Journal of Analytical and Applied Pyrolysis, 103, 86-95. http://dx.doi.org/10.1016/j.jaap.2012.10.006

[59] Manyà, J.J., Ortigosa, M.A., Laguarta, S. and Manso, J.A. (2014) Experimental Study on the Effect of Pyrolysis Pressure, Peak Temperature and Particle Size on the Potential Stability of Vine Shoots-Derived Biochar. Fuel, 133, 163172. http://dx.doi.org/10.1016/j.fuel.2014.05.019

[60] Poerschmann, J., Baskyr, I., Weiner, B., Koehler, R., Wedwitschka, H. and Kopinke, F.D. (2013) Hydrothermal Carbonization of Olive Mill Wastewater. Bioresource Technology, 133, 581-588. http://dx.doi.org/10.1016/j.biortech.2013.01.154

[61] Liu, Z., Quek, A., Hoekman, S.K. and Balasubramanian, R. (2013) Production of Solid Biochar Fuel from Waste Biomass by Hydrothermal Carbonization. Fuel, 103, 943-949. http://dx.doi.org/10.1016/j.fuel.2012.07.069

[62] Mašek, O., Budarin, V., Gronnow, M., Crombie, K., Brownsort, P., Fitzpatrick, E. and Hurst, P. (2013) Microwave and Slow Pyrolysis Biochar-Comparison of Physical and Functional Properties. Journal of Analytical and Applied Pyrolysis, 100, 41-48. http://dx.doi.org/10.1016/j.jaap.2012.11.015

[63] Larsson, S.H., Rudolfsson, M., Nordwaeger, M., Olofsson, I. and Samuelsson, R. (2013) Effects of Moisture Content, Torrefaction Temperature, and Die Temperature in Pilot Scale Pelletizing of Torrefied Norway Spruce. Applied Energy, 102, 827-832. http://dx.doi.org/10.1016/j.apenergy.2012.08.046

[64] Kappe, C.O. (2004) Controlled Microwave Heating in Modern Organic Synthesis. Angewandte Chemie International Edition (in English), 43, 6250-6284. http://dx.doi.org/10.1002/anie.200400655

[65] Sun, Y., Gao, B., Yao, Y., Fang, J., Zhang, M., Zhou, Y., Chen, H. and Yang, L. (2014) Effects of Feedstock Type, Production Method, and Pyrolysis Temperature on Biochar and Hydrochar Properties. Chemical Engineering Journal, 240, 574-578. http://dx.doi.org/10.1016/j.cej.2013.10.081

[66] Deal, C., Brewer, C.E., Brown, R.C., Okure, M.A.E. and Amoding, A. (2012) Comparison of Kiln-Derived and GasifierDerived Biochars as Soil Amendments in the Humid Tropics. Biomass and Bioenergy, 37, 161-168. http://dx.doi.org/10.1016/j.biombioe.2011.12.017

[67] Özçimen, D. and Karaosmanoğlu, F. (2004) Production and Characterization of Bio-Oil and Biochar from Rapeseed Cake. Renewable Energy, 29, 779-787. http://dx.doi.org/10.1016/j.renene.2003.09.006

[68] Prasertsan, S. and Krukanont, P. (2003) Implications of Fuel Moisture Content and Distribution on the Fuel Purchasing Strategy of Biomass Cogeneration Power Plants. Biomass and Bioenergy, 24, 13-25. 
http://dx.doi.org/10.1016/S0961-9534(02)00088-0

[69] Roy, P.C., Datta, A. and Chakraborty, N. (2009) Modelling of a Downdraft Biomass Gasifier with Finite Rate Kinetics in the Reduction Zone. International Journal of Energy Research, 33, 833-851. http://dx.doi.org/10.1002/er.1517

[70] Demirbas, A. (2004) Effect of Initial Moisture Content on the Yields of Oily Products from Pyrolysis of Biomass. Journal of Analytical and Applied Pyrolysis, 71, 803-815. http://dx.doi.org/10.1016/j.jaap.2003.10.008

[71] Mani, S., Tabil, L.G. and Sokhansanj, S. (2006) Effects of Compressive Force, Particle Size and Moisture Content on Mechanical Properties of Biomass Pellets from Grasses. Biomass and Bioenergy, 30, 648-654. http://dx.doi.org/10.1016/j.biombioe.2005.01.004

[72] Shin, D. and Choi, S. (2000) The Combustion of Simulated Waste Particles in a Fixed Bed. Combustion and Flame, 121, 167-180. http://www.sciencedirect.com/science/article/pii/S0010218099001248

[73] Aldas, R.E. (2009) Integrated Bioenergy Conversion Concepts for Small Scale Gasification Power Systems. Proquest Dissertations and Theses. Ph.D. Thesis, University of California, Davis.

[74] Guo, X., Xiao, B., Liu, S., Hu, Z., Luo, S. and He, M. (2009) An Experimental Study on Air Gasification of Biomass Micron Fuel (BMF) in a Cyclone Gasifier. International Journal of Hydrogen Energy, 34, 1265-1269. http://dx.doi.org/10.1016/j.ijhydene.2008.11.107

[75] Skoulou, V., Koufodimos, G., Samaras, Z. and Zabaniotou, A. (2008) Low Temperature Gasification of Olive Kernels in a 5-kw Fluidized Bed Reactor for $\mathrm{H}_{2}$-Rich Producer Gas. International Journal of Hydrogen Energy, 33, 6515-6524. http://dx.doi.org/10.1016/j.ijhydene.2008.07.074

[76] Lv, P.M., Xiong, Z.H., Chang, J., Wu, C.Z., Chen, Y. and Zhu, J.X. (2004) An Experimental Study on Biomass AirSteam Gasification in a Fluidized Bed. Bioresource Technology, 95, 95-101. http://dx.doi.org/10.1016/j.biortech.2004.02.003

[77] Zainal, Z.A., Rifau, A., Quadir, G.A. and Seetharamu, K.N. (2002) Experimental Investigation of a Downdraft Biomass Gasifier. Biomass and Bioenergy, 23, 283-289. http://dx.doi.org/10.1016/S0961-9534(02)00059-4

[78] Garcia-Bacaicoa, P., Bilbao, R., Arauzo, J. and Salvador, M.L. (1994) Scale-Up of Downdraft Moving Bed Gasifiers (25-300 kg/h)—Design, Experimental Aspects and Results. Bioresource Technology, 48, 229-235. http://dx.doi.org/10.1016/0960-8524(94)90151-1

[79] FAO (1985) Industrial Charcoal Making. FAO Forestry Department, Rome.

[80] Hatzilyberis, K.S. (2011) Design of an Indirect Heat Rotary Kiln Gasifier. Fuel Processing Technology, 92, 2429-2454. http://dx.doi.org/10.1016/j.fuproc.2011.08.004

[81] Bates, E. (2007) Good Technologies...But Do They Really Work? Boiling Point, 53, 3-5. http://www.hedon.info/docs/BP53-Bates-2.pdf

[82] Panwar, N.L. and Rathore, N.S. (2008) Design and Performance Evaluation of a 5kw Producer Gas Stove. Biomass and Bioenergy, 32, 1349-1352. http://dx.doi.org/10.1016/j.biombioe.2008.04.007

[83] Bantelay, D.T. and Nigus, G. (2014) Design, Manufacturing and Performance Evaluation of House Hold Gasifier Stove: A Case Study of Ethiopia. American Journal of Energy Engineering, 2, 96-102. http://dx.doi.org/10.11648/j.ajee.20140204.12

[84] Ojolo, S.J., Abolarin, S.M. and Adegbenro, O. (2012) Development of a Laboratory Scale Updraft Gasifier. International Journal of Manufacturing Systems, 2, 21-42. http://dx.doi.org/10.3923/ijmsaj.2012.21.42

[85] Downie, A., Munroe, P., Cowie, A., van Zwieten, L. and Lau, D.M.S. (2012) Biochar as a Geoengineering Climate Solution: Hazard Identification and Risk Management. Critical Reviews in Environmental Science and Technology, 42, 225-250. http://dx.doi.org/10.1080/10643389.2010.507980

[86] Cherubini, F., Bird, N.D., Cowie, A., Jungmeier, G., Schlamadinger, B. and Woess-Gallasch, S. (2009) Energy- and Greenhouse Gas-Based LCA of Biofuel and Bioenergy Systems: Key Issues, Ranges and Recommendations. Resources, Conservation and Recycling, 53, 434-447. http://dx.doi.org/10.1016/j.resconrec.2009.03.013

[87] Maccarty, N., Still, D. and Ogle, D. (2010) Fuel Use and Emissions Performance of Fifty Cooking Stoves in the Laboratory and Related Benchmarks of Performance. Energy for Sustainable Development, 14, 161-171. http://dx.doi.org/10.1016/j.esd.2010.06.002

[88] Ballard-Tremeer, G. and Jawurek, H.H. (1996) Comparison of Five Rural Wood-Burning Cooking Devices: Efficiencies and Emissions. Biomass and Bioenergy, 11, 419-430. http://dx.doi.org/10.1016/S0961-9534(96)00040-2

[89] Ballard-Tremeer, G. (1997) Emissions of Rural Wood-Burning Cooking Devices. A Thesis Submitted to the Faculty of Engineering, University of the Witwatersrand, Johannesburg, in Fulfilment of the Requirements for the Degree of Doctor of Philosophy. http://www.ecoltdgroup.com/wp-content/uploads/2011/12/PhDThesis_GrantBallard-Tremeer.pdf

[90] Zhang, J.J. and Morawska, L. (2002) Combustion Sources of Particles: 2. Emission Factors and Measurement Methods. 
Chemosphere, 49, 1059-1074. http://dx.doi.org/10.1016/S0045-6535(02)00240-0

[91] Ahuja, D.R., Joshi, V., Smith, K.R. and Venkataraman, C. (1987) Thermal Performance and Emission Characteristics of Unvented Biomass-Burning Cookstoves: A Proposed Standard Method for Evaluation. Biomass, 12, 247-270. http://dx.doi.org/10.1016/0144-4565(87)90039-4

[92] Butcher, S., Smith, R. and Osborn, J.F. (1984) Emission Factors and Efficiencies for Small-Scale Open Biomass Combustion: Toward Standard Measurement Techniques. 122-128. https://web.anl.gov/PCS/acsfuel/preprint\%20archive/Files/29_6_PHILADELPHIA_08-84_0122.pdf

[93] Cao, G., Zhang, X., Gong, S. and Zheng, F. (2008) Investigation on Emission Factors of Particulate Matter and Gaseous Pollutants from Crop Residue Burning. Journal of Environmental Sciences (China), 20, 50-55. http://dx.doi.org/10.1016/S1001-0742(08)60007-8

[94] Darley, E.F., Burleson, F.R., Mateer, E.H., Middleton, J.T. and Osterli, V.P. (1966) Contribution of Burning of Agricultural Wastes to Photochemical Air Pollution. Journal of the Air Pollution Control Association, 16, 685-690. http://dx.doi.org/10.1080/00022470.1966.10468533

[95] Janvijitsakul, K. and Kuprianov, V.I. (2008) Major Gaseous and PAH Emissions from a Fluidized-Bed Combustor Firing Rice Husk with High Combustion Efficiency. Fuel Processing Technology, 89, 777-787. http://dx.doi.org/10.1016/j.fuproc.2008.01.013

[96] Albina, D.O. (2006) Emissions from Multiple-Spouted and Spout-Fluid Fluidized Beds Using Rice Husks as Fuel. Renewable Energy, 31, 2152-2163. http://dx.doi.org/10.1016/j.renene.2006.02.013

[97] Kuprianov, V.I., Kaewklum, R., Sirisomboon, K., Arromdee, P. and Chakritthakul, S. (2010) Combustion and Emission Characteristics of a Swirling Fluidized-Bed Combustor Burning Moisturized Rice Husk. Applied Energy, 87, 2899-2906. http://dx.doi.org/10.1016/j.apenergy.2009.09.009

[98] Thao, P.T.M., Kurisu, K.H. and Hanaki, K. (2011) Greenhouse Gas Emission Mitigation Potential of Rice Husks for An Giang Province, Vietnam. Biomass and Bioenergy, 35, 3656-3666. http://dx.doi.org/10.1016/j.biombioe.2011.05.023

[99] Galinato, S.P., Yoder, J.K. and Granatstein, D. (2011) The Economic Value of Biochar in Crop Production and Carbon Sequestration. Energy Policy, 39, 6344-6350. http://dx.doi.org/10.1016/j.enpol.2011.07.035

[100] Torres-Rojas, D., Lehmann, J., Hobbs, P., Joseph, S. and Neufeldt, H. (2011) Biomass Availability, Energy Consumption and Biochar Production in Rural Households of Western Kenya. Biomass and Bioenergy, 35, 3537-3546. http://dx.doi.org/10.1016/j.biombioe.2011.05.002

[101] Luoga, E., Witkowski, E.T. and Balkwill, K. (2000) Economics of Charcoal Production in Miombo Woodlands of Eastern Tanzania: Some Hidden Costs Associated with Commercialization of the Resources. Ecological Economics, 35, 243-257. http://dx.doi.org/10.1016/S0921-8009(00)00196-8

[102] Islam, M.N. and Ani, F.N. (2000) Techno-Economics of Rice Husk Pyrolysis, Conversion with Catalytic Treatment to Produce Liquid Fuel. Bioresource Technology, 73, 67-75. http://dx.doi.org/10.1016/S0960-8524(99)00085-1

[103] Roberts, K.G., Gloy, B.A., Joseph, S., Scott, N.R. and Lehmann, J. (2010) Life Cycle Assessment of Biochar Systems: Estimating the Energetic, Economic, and Climate Change Potential. Environmental Science \& Technology, 44, 827833. http://dx.doi.org/10.1021/es902266r

[104] Shabangu, S., Woolf, D., Fisher, E.M., Angenent, L.T. and Lehmann, J. (2014) Techno-Economic Assessment of Biomass Slow Pyrolysis into Different Biochar and Methanol Concepts. Fuel, 117, 742-748. http://dx.doi.org/10.1016/j.fuel.2013.08.053

[105] Granatstein, D., Collins, H., Garzia-Perez, M. and Yuder, J. (2009) Use of Biochar from Pyrolysis of Waste Organic Material as a Soil Amendment. Final Report, Center for Sustaining Agriculture and Natural Resources, Washington State University, Washington, 168. 